IZA DP No. 10130

The Lasting Effect of Sex Ratio Imbalance on Marriage and Family: Evidence from World War II in Russia

Elizabeth Brainerd

August 2016 


\title{
The Lasting Effect of Sex Ratio Imbalance on Marriage and Family: Evidence from World War II in Russia
}

\author{
Elizabeth Brainerd \\ Brandeis University \\ and IZA
}

Discussion Paper No. 10130

August 2016

\author{
IZA \\ P.O. Box 7240 \\ 53072 Bonn \\ Germany \\ Phone: +49-228-3894-0 \\ Fax: +49-228-3894-180 \\ E-mail: iza@iza.org
}

Any opinions expressed here are those of the author(s) and not those of IZA. Research published in this series may include views on policy, but the institute itself takes no institutional policy positions. The IZA research network is committed to the IZA Guiding Principles of Research Integrity.

The Institute for the Study of Labor (IZA) in Bonn is a local and virtual international research center and a place of communication between science, politics and business. IZA is an independent nonprofit organization supported by Deutsche Post Foundation. The center is associated with the University of Bonn and offers a stimulating research environment through its international network, workshops and conferences, data service, project support, research visits and doctoral program. IZA engages in (i) original and internationally competitive research in all fields of labor economics, (ii) development of policy concepts, and (iii) dissemination of research results and concepts to the interested public.

IZA Discussion Papers often represent preliminary work and are circulated to encourage discussion. Citation of such a paper should account for its provisional character. A revised version may be available directly from the author. 


\section{ABSTRACT}

\section{The Lasting Effect of Sex Ratio Imbalance on Marriage and Family: Evidence from World War II in Russia*}

How does a shock to sex ratios affect marriage markets and fertility? I use the drastic change in sex ratios caused by World War II to identify the effects of unbalanced sex ratios on Russian women. Using unique data from the Soviet archives, the results indicate that male scarcity led to lower rates of marriage and fertility, higher nonmarital births and reduced bargaining power within marriage for women most affected by war deaths. The impact of sex ratio imbalance on marriage and family persisted for years after the war's end, and was likely magnified by policies that promoted nonmarital births and discouraged divorce.

JEL Classification: J12, J16, N34, P23

Keywords: sex ratios, marriage, family, fertility, divorce law

Corresponding author:

Elizabeth Brainerd

Department of Economics

Brandeis University

Mailstop 021, 415 South Street

Waltham, MA 02453-2728

USA

E-mail: ebrainer@brandeis.edu

\footnotetext{
* This is a significantly revised version of a paper previously circulated as "Uncounted Costs of World War II: The Effect of Changing Sex Ratios on Marriage and Fertility of Russian Women." I thank Josh Angrist, Ralph Bradburd, Erik Craft, Scott Cunningham, Claudia Goldin, Timothy Heleniak, Lawrence Katz, Olga Malkova, Robert Margo, Derek Neal, Steffen Reinhold, Lucie Schmidt and seminar participants at Brandeis University, CUNY Graduate Center, Davis Center for Russian and Eurasian Studies, Harvard joint Public Finance/Economic History Workshop, Radcliffe Institute for Advanced Study, Society of Labor Economists 2008 Annual Meetings, the University of Kentucky, and the Williams College Economics Department for helpful comments on earlier versions of this paper.
} 
In many ways the Soviet Union was built on the backs of Russian women. Pulled into the labor force by the intense industrialization drive of the 1930s and indispensable for fueling the Soviet war machine of the 1940s, the experience of Russian women of the twentieth century was profoundly different from that of women in most industrialized countries. These differences are evident in the high female labor force participation rates, low fertility rates, and strikingly high abortion rates recorded in the Soviet Union over its history. Yet due to limited data, much remains unknown about the changing lives of Russian women over the twentieth century and how women's lives were affected by the many upheavals that marked the country during this turbulent period.

This paper examines the effect of one cataclysmic event, the massive loss of life in World War II, on the subsequent marital and fertility careers of Russian women. For women in the cohorts most affected by the war, these losses resulted in extremely unbalanced sex ratios in the population: for women age $20-29$, for example, the ratio of men to women in the population fell from .91 in 1941 to .65 in 1946 . Using unpublished Census and vital statistics data collected from the Soviet archives in Moscow, this paper uses this large, exogenous change in the sex ratio to identify the effects of highly unbalanced sex ratios on the marital and fertility outcomes of Russian women in the postwar period. Despite the elapsed years between the end of World War II and the first postwar census of 1959, the results indicate that the relative scarcity of men continued to profoundly affect women's lives: women were less likely to marry, more likely to give birth out of wedlock, and more likely to be divorced in the birth cohorts and regions facing the greatest shortages of men. The unbalanced sex ratios also affected intrahousehold bargaining power among married couples by influencing marital fertility and by increasing the share of marriages with a large age gap between bride and groom. The unique institutional context of the 
postwar Soviet Union, featuring significant increases in the relative cost of marriage for men, likely exacerbated the effects of male shortage by further reducing men's propensity to marry.

The results of this paper underscore the conclusions of a growing body of research demonstrating that conditions in the marriage market have profound and long-lasting effects on individuals and society as a whole. Recent research in this literature has explored the impact of high male incarceration rates on women (Charles \& Luoh, 2010; Mechoulan, 2011), the influx of mainland Chinese to Taiwan in 1949 (Francis, 2011), and the effect of unbalanced sex ratios in the U.S. immigrant population (Angrist, 2002; LaFortune, 2013). The results of these papers generally support the predicted effects of sex ratio imbalance on marriage markets and intrahousehold bargaining power as first developed by Becker $(1973,1974,1981):^{1}$ in conditions of male scarcity, women are less likely to marry, more likely to have children out of wedlock, more likely to work, and more likely to invest in their human capital. The cultural attitudes fostered by significant sex ratio imbalance, such as attitudes towards women's work outside the home, appear to persist over long periods of time (Grosjean \& Khattar 2014).

Two recent papers have explored the impact of male scarcity due to wars on marriage markets and fertility. Abramitzky et al. (2011) examine the impact of male deaths in World War I in France on the postwar marriage market. Using Census and marriage-level data for before and after the war, the authors demonstrate a significant impact of low sex ratios on marriage and fertility, in particular that men use their advantageous position in the marriage market to 'marry up' and marry women of a higher social class. These findings illustrate that an additional mechanism through which marriage markets can adjust to sex imbalances is through a change in

${ }^{1}$ See also Guttentag \& Secord (1983), Grossbard-Shechtman (1993) and Chiappori et al. (2002) for contributions in this literature. Other papers examine the effect of unbalanced sex ratios on savings rates (Wei \& Zhang, 2011) and crime (Edlund et al., 2013). 
assortative matching. Bethmann \& Krasickova (2013) analyze how the loss of men in World War II affected out of wedlock births in Bavaria. Using county-level data and instrumenting for the sex ratio using male war deaths, the results indicate that regions with greater loss of male life experienced significantly higher shares of out of wedlock births after the war.

This paper adds to this literature by analyzing the effect of World War II in Russia, a country that has not been previously studied in this context and which suffered large-scale losses during the war. To overcome the possible endogeneity between sex ratios and marital outcomes, I use sex ratios that vary by year of birth within Russian oblasts, ${ }^{2}$ which allows me to exploit the sharp discontinuities in the sex ratio by age and to control for the many potential confounding factors which differ across oblasts but are unlikely to vary by year of birth within oblasts. This paper also highlights the importance of a country's institutional context for understanding the impact of sex ratio imbalance on marriage markets and family formation: the ease or difficulty

of divorce, combined with any legal obligations to support children fathered out of wedlock, may influence whether male scarcity results in increased or decreased commitment to marriage and family. This point has received little attention in the literature on sex ratios and marriage markets.

\section{The impact of World War II on the Soviet population}

On June 22, 1941, Hitler's Wehrmacht invaded the Soviet Union to initiate what would become one of the most brutal and costly wars between two countries in history. The surprise attack on the woefully unprepared Red Army led to devastating losses for the Soviet Union in the

\footnotetext{
${ }^{2}$ The term 'oblast' refers to the territorial subdivisions of the Soviet republics, called oblasts, krais, or autonomous republics in Russian, which are roughly equivalent to U.S. states. 'Region' is used interchangeably with 'oblast' in the text. This is distinct from the 'large regions' shown in Figure 2 (North, Northwest, etc.) which are similar to U.S. Census divisions.
} 
early phase of the war: within the first six months, the Red Army had lost nearly 5 million men the size of the Soviet Union's entire prewar army - and had lost territory equal to the size of the United States between the East Coast and Springfield, Illinois (Glantz, 2005).

The Soviet Union mobilized all of its resources in its subsequent fight for survival and victory. The need for manpower dictated a significant loosening of the age and nationality restrictions on conscription; men under age 18 and over 55 were conscripted into the Red Army, with residents of all fifteen Soviet republics required to serve (Glantz, 2005). Including individuals serving at the beginning of the war, 34.5 million people were drafted into the armed forces during the war, of which nearly 8.7 million died in combat (Krivosheev et al., 1997).

The total losses sustained by the Soviet Union during World War II remain a topic of controversy among scholars, and an exact accounting of the deaths may never be known. The most reliable figures are those of an expert commission which estimated the total excess deaths at 26 to 27 million or roughly 13.5 percent of the prewar population (Andreev et al., 1990). The losses in the Russian republic were similar: approximately 13.6 million died, or 12.3 percent of the 1941 population. To put these losses in context, the total civilian and military casualties in Germany during World War II were 5-7 million (6-9 percent of the 1939 population), while France and the U.K. lost less than 2 percent of their prewar population in the war.

Although people of all ages fell victim to the war, whether due to death in military operations, at the hands of occupiers, or due to the widespread undernutrition and disease that accompanied the war, the wartime casualties were nevertheless heavily concentrated among young men; an estimated 20 million of the 26-27 million excess deaths were male (Ellman \& Maksudov, 1994). Russian demographers calculate that the probability of surviving between 1941 and 1946 for men age 25-34 fell from .96 - the probability in the absence of the war based 
on 1940 mortality rates - to .61, and estimate that women age $20-39$ outnumbered men in the Soviet Union by 10.2 million in 1946 (Andreev et al., 1993). The resulting decrease in the sex ratio is illustrated in Figure 1, which plots the ratio of men to women by single year of age in 1959 in Russia. The cohorts most affected by the war were in their teens to early twenties at the beginning of the war, and extended to include those in their thirties, born in the first decades of the twentieth century. While women in the prewar Soviet Union already contended with sex ratios below 1.0 due to the 1917 Revolution, World War I and Civil War, the sex ratio fell dramatically for individuals born in the 1920 s and reached a low of 0.60 for women born in 1924. The sex ratio returned to approximately 1.0 for those born in 1935 and after.

Along with its age and sex structure, the war changed the regional distribution of the population in the USSR. The western regions of the country experienced most of the fighting and sustained the greatest war losses. These losses, combined with the evacuation of millions of people eastward, led to a shift of nearly 4 percent of the population from western to eastern regions of the Soviet Union between 1939 and 1951 (Rowland, 1997). Over 1,500 factories were also relocated to east of the Volga River during the war (Barber \& Harrison, 1991).

The profound impact of the war on the age and sex structure of the population across Russia's regions is illustrated in Figure 2, which shows sex ratios by region in 1959 for individuals age 25-29 and 35-39. Sex ratios for the 35-39 year-old cohort are around 0.60 in most regions, as compared with approximately 1.0 for the age $25-29$ cohort that was largely unaffected by war deaths. Sex ratios for both groups are highest in the North, East Siberia and Far East, which attract disproportionately male workers to work in the natural resource sectors of the economy located in those regions. Although the occupation and physical destruction of the country occurred in the west, Figure 2 illustrates that male deaths (as proxied by the sex ratio) 
occurred across all regions of the country in roughly similar proportion. This is also true of the other Soviet republics; see Online Appendix Table 1 which provides sex ratios by Soviet republic and RSFSR region for the 25-29 and 35-39 age groups.

Besides the massive loss of civilian and military lives during the war, an additional demographic cost was the decline in births during the war years. The birth rate fell from 34.6 per 1,000 population in 1940 to 26.0 in 1946; an estimated 11.5 million births did not occur because of the war (Ellman \& Maksudov, 1994). Demobilization after the war took three years, further delaying the return to normal family-formation patterns until the late 1940s. This is evident in the sharp increase in age at first marriage for Russian women in the cohorts most affected by the war (see Figure 3). Despite late marriage, these women appear to have completed fertility similar to that of women in nearby cohorts. Some demographers argue that the war ultimately had little impact on the marital and fertility careers of Russian women as most women eventually married and had two children (Scherbov \& Van Vianen, 2001). The analysis presented below suggests in contrast that the unbalanced sex ratios did affect fertility and family formation, as well as out of wedlock births, the spousal age gap and marital stability.

Alarmed at the devastating population losses suffered by the country and the declining birth rate, the Soviet government implemented a strongly pronatalist Family Code in 1944. This legislation imposed a tax on single people and married couples with fewer than three children, and expanded the child benefit program to provide a monthly payment for all children born out of wedlock (Heer, 1977). Far from discouraging nonmarital births, the 1944 law absolved fathers of any financial or legal responsibility for children fathered outside of marriage; unmarried mothers were prohibited from naming the father on the birth certificate or claiming financial support for their children. The 1944 Family Code also made the procedure for divorce so expensive and 
complicated that it has been described as effectively a "prohibition on divorce" (Avdeev \& Monnier, 2000). The high cost of divorce combined with nearly costless nonmarital sexual relations significantly increased the cost of registered marriage relative to bachelorhood for men. While Soviet leaders promoted the 1944 Family Code as a means to strengthen the family, the unique institutional context created by these laws likely exacerbated the effect of male shortage on male behavior and women's outcomes, reducing registered marriage and increasing marital instability. These effects are investigated in the statistical analysis below.

\section{Data sources}

The primary empirical strategy exploits the differences in the sex ratio by year of birth and region to identify the effect of unbalanced sex ratios on marriage and fertility in Russia. The data used in the analysis are unpublished data from the 1959 Soviet Census and the 1959 Soviet vital statistics registry, collected and digitized by the author from records in the Soviet archives. The Census data comprise the distribution of the population by sex, marital status, and urban/rural area by single year of age for each of the 75 regions of the Russian Soviet Federal Socialist Republic (RSFSR). ${ }^{3}$ The vital statistics data include the number of births by marital status in each region, the number of marriages by age of bride and groom, the number of divorces, and the number of deaths due to abortion in 1959; most of the vital statistics data are given by 5 -year age group as detailed in Table $1 .^{4}$ These data are combined with the Census

\footnotetext{
${ }^{36}$ Marital status' indicates whether an individual is currently married; no information is available on divorce, previous marriages, or widowhood. The terms 'RSFSR', 'Russian republic,' and 'Russia' are used interchangeably to refer to the Russian Soviet Federal Socialist Republic.

${ }^{4}$ The data are from the State Archive of the Russian Federation and the Russian State Archive of the Economy; see the online Data Appendix for details.
} 
population data to calculate birth rates by marital status, marriages by spousal age gap, divorce rates and abortion death rates by five-year age group and region for $1959 .{ }^{5}$

The analysis focuses on individuals age 18 to 44 in 1959, i.e. born in 1915 to 1941. This age range is selected because it is the age during which most decisions regarding marriage and fertility are made; as shown in Figure 1 it also captures the cohorts most affected by the decline in the sex ratio, along with nearby cohorts who were less affected by war deaths. The sex ratio is calculated as the number of men from two years younger to ten years older than women of a given age, divided by the number of women in the same age range. For example, for women age 22 in 1959, the sex ratio is defined as the number of men age 20 to 32 divided by the number of women age 20 to 32; for women age 20-24 in 1959 the sex ratio is calculated as the number of men age 18 to 34 divided by the number of women of the same age.

Descriptive statistics are given in Table 1; Online Appendix Table 2 provides descriptive statistics by five-year age group. The sex ratio is .796 for the population as a whole and varies widely across birth cohorts and regions. A relatively low proportion of women (61.8 percent) were married in 1959, and only 64.8 percent of men. Birth rates are lower for urban than for rural women (81.2 versus 126.5 births per 1,000 women, respectively); the birth rate for married women is 185.5 births per 1,000 married women while the unmarried birth rate is 43.2 births per 1,000 unmarried women. Out of wedlock births accounted for nearly 16 percent of births in Russia in 1959, compared with 5.3 percent of births in the U.S. in 1960. Note that because abortion was legalized in the USSR in 1955 and was a widely-used means of controlling births in the Soviet Union, nonmarital births represent a conscious choice to have a child outside of

\footnotetext{
${ }^{5}$ Age heaping at ages 30 and 40 is evident in the rural Census data. The sex ratio measure used here, with numerator and denominator spanning the same ages, helps to minimize measurement error due to this problem, providing that men and women are similar in their age misreporting.
} 
marriage. Of marriages registered in 1959, 7.1 percent had a bride and groom with at least an 11year age gap between them. ${ }^{6}$ The divorce rate was 8.8 per 1,000 married population and is much higher for the urban population (13.1 per 1,000 married population) than for the rural population (3.4 per 1,000). For comparison, the crude divorce rate in Russia was 1.4 per 1,000 population in 1959 versus 2.2 per 1,000 population in the U.S. in 1960 . Table 1 also indicates the high number of deaths due to abortion, at .108 per 100 births. Female employment rates were high, with 73.3 percent of women age 16-44 employed in 1959.

Aside from basic indicators such as proportion married and age-specific birth rates, most of these data have never been published; in fact some of the data, such as deaths due to abortion, are marked as "top secret" in the archives and only became available to researchers in the 1990s. As a result, it is difficult to assess the reliability of the data. Where comparable published data are available, the archival data match the published data quite closely. For example, the archival data match the proportion married for men and women age 18 to 44 exactly; the age-specific birth rates are also close (see Online Appendix Table 2). The quality of the underlying Census and vital statistics data is more difficult to assess. The 1959 Census data are considered to be relatively high quality (Anderson et al. 1994), although age heaping is evident in the age distribution data. Registration of vital events was nearly complete in Russia by 1959 , but nonmarital births were almost certainly under-registered due to the stigma of having an unnamed father on a child's birth certificate. Demographers estimate that 5 percent of births were not registered in the USSR in this period, with rural births less accurately recorded than urban births (Anderson \& Silver, 1986). Deaths due to abortion are likely under-reported as well.

\footnotetext{
${ }^{6}$ Since age at marriage is recorded in 5-year age groups, the spousal age gap is difficult to calculate. Here 'large age gap' is assigned if, for example, a bride in the 20-24 age group marries a groom in the 35-39 age group or any age group older than that.
} 


\section{$\underline{\text { III. Empirical strategy and main regression results }}$}

The regressions are estimated as fixed effects regressions which stack the data by single year of birth, or 5-year age group, and region:

$$
\mathrm{Y}_{\mathrm{cj}}=\beta_{1} \mathrm{R}_{\mathrm{cj}}+\beta_{2} \ln \left(\text { pop }_{\mathrm{cj}}\right)+\lambda_{\mathrm{c}}+\mu_{\mathrm{j}}+\varepsilon_{\mathrm{cj}}
$$

where $\mathrm{R}_{\mathrm{cj}}$ is the sex ratio for birth cohort $c$ in region $j ; \lambda_{\mathrm{c}}$ are birth cohort fixed effects; $\mu_{\mathrm{j}}$ are region fixed effects, and $Y_{\mathrm{cj}}$ is an outcome such as the proportion married, the birth rate, divorce rate, and so on. The birth cohort fixed effects are dummy variables for single year of birth or 5year birth cohort, depending on data availability. As has become standard in this literature, all regressions include the log of the size of the population of the opposite sex which controls for the thickness of the marriage market. The regressions are estimated for women or men age 18-44 in 1959 or a similar age group as dictated by data availability. Because matching in the marriage market may differ between urban and rural areas (the marriage market in urban areas is likely to be 'thicker' than in rural areas, and social norms regarding marriage and child bearing may differ between rural and urban areas), the regressions are also estimated for urban and rural areas separately. Standard errors are adjusted for clustering by region, which allows for serial dependence in the errors within regions (Bertrand et al., 2004).

\section{a. Identification}

The basic estimating equation (1) includes birth cohort and region fixed effects. The birth cohort effects control for differences across birth cohorts that are common across regions in 1959 , such as length of exposure to the 1955 legalization of abortion which varies by year of birth and may have affected past and therefore current fertility decisions. The region fixed effects control for unobserved, unchanging characteristics of Russia's regions, such as cultural 
differences in attitudes toward marriage, that are assumed to be unchanging across birth cohorts but may affect fertility and marital outcomes. In this base specification the coefficient of interest, $\beta_{1}$, is identified from differences in the sex ratio between single year (or five year) birth cohorts within the same region. The key identifying assumption is that differences in sex ratios across cohorts are exogenous to economic and social conditions that may affect marriage markets and fertility outcomes, and in particular that there are no omitted variables that are correlated with the sex ratio and related to the outcomes in the analysis.

At the national level it is plausible that the change in sex ratios was an exogenous shock: as is well known, the German attack on the USSR in 1941 was a surprise to Soviet leaders and the Soviet population. ${ }^{7}$ Little emigration or immigration was permitted in the early postwar period, so for the country as a whole the sex ratio would have been unaffected by these factors.

However much of the concern regarding the endogeneity of sex ratios and marital outcomes relates to internal migration, i.e. that cross-regional migration within Russia may have occurred in the early postwar period that was correlated with both sex ratios and marriage market conditions in the regions. For example, women faced with unfavorable prospects in the marriage market may have migrated to relatively high sex ratio areas in the Far East, where men earned high wages in the natural resource sector and were attractive marriage prospects. This seems unlikely in the postwar Soviet Union, however. While data are limited, the evidence suggests that cross-regional migration rates were low due to the severe housing shortage in the Soviet Union and the use of residence permits in many cities. ${ }^{8}$ For example, the net urban migration

${ }^{7}$ The German-Soviet Non-Aggression Pact was signed on August 23, 1939. Glantz (1998) describes the unpreparedness of the Red Army for war in 1941.

${ }^{8}$ Residence permits ("propiska") were implemented in 1932 to control population movement. To obtain a propiska for a city required confirmed employment in that city; however a propiska was 
rate for Russia was 24.3 per 1,000 population in 1950 and 16.6 in 1959; the net rural migration rate was even lower (Goskomstat of Russia, 1998). Moreover, cross-regional migration is only weakly correlated with the regional population losses during the war: the correlation between the change in population by region between 1939 and 1951 - a proxy for the physical and population losses suffered in each region - and the urban in-migration rate in 1960 is .08.

It is also striking that across the vast expanse of the Soviet Union, there were virtually no regions that were spared the human loss of the war: every USSR republic, from the Baltics to Central Asia, suffered large losses of life and highly unbalanced sex ratios (see Online Appendix Table 1). Even if migration were free and housing were readily available, few, if any, regions in Russia or the Soviet Union in the postwar aftermath would be attractive to women looking to improve their outcomes on the marriage market. It is more likely that women 'migrated' across age groups within their region than migrated across regions to find eligible partners. This response to male scarcity in the marriage market is tested below.

Aside from endogenous internal migration, a second threat to internal validity is from regional economic losses: the regions with the largest population losses likely suffered the greatest economic losses through the physical devastation that resulted from battles in the occupied territories. The economic losses could affect marriage markets indirectly through the impact on the employment prospects of men and women and by further exacerbating the housing shortage. The ethnic structure of the population was altered as well, primarily due to the destruction of the Jewish population (Acemoglu et al., 2011). The full set of region and birth

necessary to be offered a job - a classic Soviet "catch 22" situation. Only urban residents had the right to hold an internal passport; rural residents obtained this right in 1974 and had no right to move even within their oblast of residence. The internal migration that did occur in the USSR in this period was state-driven and mainly comprised employment-led resettlements or forced resettlements of ethnic groups to remote regions of the USSR (Ivakhnyuk, 2009). 
cohort dummies in the regressions will absorb much of these effects, and it is unlikely that the impact of the economic losses varied by year of birth in a way that would be correlated with the change in the sex ratio within regions. The loss of the Jewish population affected both men and women so is unlikely to be strongly correlated with the sex ratio. The regressions are also estimated including region-specific linear cohort trends which control for gradually evolving regional characteristics of cohorts. While it would be useful to test the robustness of the results by using war deaths as an instrument for the sex ratio, as in Abramitzky et al. (2011) and Bethmann \& Kvasnicka (2013), there are no publicly available data on war deaths by region or age group, and war deaths cannot be reliably estimated due to the 20 -year gap between Census enumerations in 1939 and 1959.

\section{b. Results}

The first set of regressions uses the share of women or men currently married as the dependent variable; results are shown in Table 2a. Each cell in the table reports the coefficient on Sex Ratio from a separate regression. Regressions are estimated without weights (columns 1 and 3) and weighting by population (columns 2 and 4), and including region-specific cohort trends (columns 3 and 4). For women, a lower sex ratio is associated with a lower proportion married; this effect is statistically significant for the population as a whole and for the urban population, but is statistically insignificant for the rural population in most specifications. ${ }^{9}$ Using the base specification in column (1), the coefficient on the sex ratio for women (.149) indicates

\footnotetext{
${ }^{9}$ In this and following tables, the standard errors for the rural regressions are often much larger than those for the urban regressions, suggesting greater measurement error in the dependent variable for the rural population. This is consistent with the higher incidence of age heaping and the less accurate vital registration reporting for the rural population discussed above.
} 
that the roughly two-standard deviation decrease in the sex ratio that occurred due to the war is associated with a 5.0 percentage point decrease in the share of married women, or an 8 percent decrease in the average marriage rate for women. Including regional cohort trends in the regression increases the magnitude of the coefficients but does not affect the statistical significance of the estimates. The use of population weights has little effect on the magnitude or statistical significance of the results in most specifications, although the OLS estimates are generally more efficient. ${ }^{10}$

The results for men are smaller in magnitude and often statistically insignificant in the base specification (columns 1 and 2) but are positive and statistically significant when regionspecific cohort trends are included in the regressions (columns 3 and 4). Because cohort trends almost certainly affect the demographic outcomes examined here and likely vary by region, the preferred specification includes the region-specific cohort trends, ${ }^{11}$ so I focus on these results for men and in further discussion. The coefficient on Sex Ratio for men is .178 (column 3), indicating that a two-standard deviation decrease in the sex ratio is associated with a 6 percentage point decrease in the share of men who were married in 1959 , or a 9 percent decrease in the average male marriage rate.

This positive relationship between the sex ratio and the male proportion married contradicts Becker's prediction of a negative relationship between the two, and is also the opposite of Abramitzky et al.'s finding (2011) that greater male scarcity in France after WWI increased the probability of male marriage. The unique institutional environment of the Soviet

\footnotetext{
${ }^{10}$ Solon et al. (2015) discuss the use of weights when the data are group averages. While WLS is often employed to correct for heteroskedasticity in group population data, as discussed in Solon et al. the OLS estimator can yield more precise estimates than WLS in some circumstances.

${ }^{11} \mathrm{~F}$-tests reject the null hypothesis that the region-cohort trends are jointly zero in all regressions.
} 
Union may explain this result, as costly divorce and (financially and legally) costless nonmarital fatherhood for men may have deterred men from making legally binding commitments through marriage. Archival research of court records indicates that men preferred to avoid registered marriage and divorce altogether in this era, or, if already in a registered marriage, felt free to leave their wives for another partner without bothering to file for divorce (Nakachi, 2006, 2008). ${ }^{12}$ Rather than strengthening the family as intended, the 1944 Family Code appears to have weakened the family and reduced the likelihood that men marry.

To further investigate the impact of family law on marriage in a low sex ratio environment, Table $2 \mathrm{~b}$ estimates the same regressions as in Table $2 \mathrm{a}$ (column 3) using the 1926 Russian Census. The sex ratio was .868 in this period due to the disproportionate loss of men in earlier wars. Data are in 5-year age groups (except for age 18-19); the same regressions using the 1959 Census are shown in columns (3) and (4) for comparison. The 1920s were characterized by ultra-liberal unilateral divorce laws ${ }^{13}$ and the requirement that fathers provide support to all children, legitimate and illegitimate. Both of these significantly reduced the cost of marriage relative to bachelorhood for men compared with the 1959 regime. As shown in Table $2 b$, the impact of low sex ratios on the proportion of men and women married in 1926 differs markedly from that of 1959. Focusing on the urban population results (which are less affected by age heaping, especially in the 1926 Census), the standard errors of the estimates are almost identical in the 1926 and 1959 regressions. But the coefficients on Sex Ratio are much smaller in magnitude and statistically insignificant for the 1926 regressions. This suggests that the impact

\footnotetext{
${ }^{12}$ This behavior is consistent with the male-female discrepancy in reported marriage in the 1959 Census, in which about 250,000 more women than men report they are currently married.

${ }^{13}$ In 1926 a wife or husband could unilaterally file for divorce in a local registration office; the spouse would be notified of the divorce three days later by postcard (see Moskoff, 1983).
} 
of male scarcity on marriage probabilities is reduced when the cost of marriage is relatively low (although it is also consistent with greater attenuation bias in the 1926 regressions).

Returning to the 1959 results, a second set of regressions tests the effect of the sex ratio on overall birth rates (Table 3). Focusing on the preferred specification in columns 3 and 4, birth rates are higher for women in cohorts with higher sex ratios; the results are qualitatively similar when birth rates are in logs (columns 5 and 6). This result is as expected since most births took place within marriage; the lower marriage rates for women resulting from low sex ratios would therefore result in lower birth rates. Using the coefficient in column (3), a two-standard deviation decrease in the sex ratio is associated with a decline of 54 births per 1,000 women age 18-44, a quantitatively large effect ${ }^{14}$ indicating that the lingering impact of low sex ratios on the likelihood of female marriage and therefore birth rates further exacerbated the population loss of World War II by reducing births in the postwar years.

Table 4 shows the results of regressions of the sex ratio on other demographic outcomes; to conserve space, results are shown including region-specific cohort trends only. Columns 1 and 2 test whether the sex ratio affects marital fertility. The results indicate that a lower sex ratio is associated with fewer marital births; in other words, when men are scarce - and therefore have a stronger bargaining position within marriage - the birth rate among married women is lower. One explanation for this relationship may be differing preferences for children, with men preferring fewer children than women and having greater influence on fertility choices given their stronger bargaining position (no data exist on desired fertility of men and woman in Russia

\footnotetext{
${ }^{14}$ This magnitude implies a decline in the total fertility rate (TFR) of 1.4, a large effect compared with the TFR in Russia of 2.63 in 1959. However the birth rate used here is a period rate which can be biased by changes in the timing of births (Newell, 1994). The results for completed fertility, discussed below, are a more reliable indicator of the effect of low sex ratios on fertility.
} 
for this period, however). Another possible explanation is female labor supply, with married women working more in a low sex ratio environment, leading to lower marital birth rates. However, when a control for the female employment to population ratio is included in the regression, the coefficient on the sex ratio remains positive and statistically significant (discussed below). A third possibility is that in regions and cohorts with lower sex ratios, marriages are more unstable: men are more likely to leave a marriage for another partner but remain legally married to the original spouse, leading married women to reduce their fertility. One can conjecture that the low-sex ratio environment of postwar Russia had additional detrimental effects on wives given their weak bargaining power; for example domestic abuse rates might be higher and, with few outside options, women might rationally decide to remain in abusive relationships. However, data limitations preclude statistical testing of these predictions. ${ }^{15}$

Unmarried women also had weak bargaining power in the aftermath of the war; given the relative scarcity of men unmarried women may have felt increased pressure to engage in nonmarital sexual relations which, due to the lack of contraceptives in the Soviet Union, may have led to an increase in nonmarital births as well as unwanted pregnancies and abortions. A regression of the nonmarital birth rate on the sex ratio supports this prediction, indicating that a two-standard deviation decrease in the sex ratio is associated with an increase in nonmarital births of 68 per 1,000 unmarried women (column 3), a large increase over the average nonmarital birth rate $(43$ per 1,000$)$. While this effect is quantitatively large, it is plausible given the state financial support of unmarried mothers during this period (the relationship between the nonmarital birth rate and the sex ratio is sensitive to the use of weights, however). The increase

\footnotetext{
${ }^{15} \mathrm{~A}$ regression of the female homicide rate on the sex ratio (and controls) shows a negative relationship, as predicted, but the coefficient is statistically insignificant in all specifications.
} 
in nonmarital births in Russia contrasts with the effects of war mortality in Bavaria, which indicate a rise in the out of wedlock birth ratio largely driven by declining overall fertility rather than increased nonmarital births (Bethmann \& Krasickova 2013). State transfer payments for unwed mothers had declined significantly in postwar Germany, in contrast to Russia, underscoring that differences in the institutional environment likely affect the impact of low sex ratios on nonmarital fertility. Columns (5) and (6) of Table 4 indicate that the share of nonmarital births is negatively related to the sex ratio for urban women, and the effect is economically significant. The coefficient on the sex ratio (column 5) indicates that a twostandard deviation decrease in the sex ratio is predicted to increase the proportion of out of wedlock births by 2.6 percentage points, or 19 percent of the share of nonmarital births (14.0 percent) in urban areas. The effect of the sex ratio in rural areas is statistically insignificant, possibly due to greater measurement error in the reporting of rural nonmarital births.

Urban-rural differences are also evident in the impact of the sex ratio on the spousal age gap (columns 7 and 8) and on the divorce rate (columns 9 and 10). In urban marriage markets, the decline in the sex ratio is associated with a significant increase in the proportion of marriages with a large age gap between bride and groom, and with an increase in the divorce rate (the latter is significant for the urban population in the weighted regression only). These results are consistent with women marrying men outside of the typical age range as a means of adjusting to relative male scarcity. The higher divorce rate could reflect a lower quality of matches in the marriage market, perhaps due to a decrease in assortative matching (Abramitzky et al., 2011). A higher divorce rate in a low sex ratio environment is also consistent with 'serial polygamy,' in which better outside options for men lead men to marry, divorce and remarry at higher rates than would be the case in a high sex ratio environment (Becker, 1974, 1981). 
The last regressions in Table 4 regress the death rate from abortion on the sex ratio. The death rate from abortion is calculated as the number of deaths due to abortion in each age group divided by the number of births in each age group (to adjust for differing fertility rates); the number of women obtaining abortions is unavailable for 1959. The coefficients on Sex Ratio for the whole population and the urban population (columns 11 and 12) are insignificant with large standard errors; the sign for the rural population in both columns is negative, as expected, but is statistically insignificant. As in the divorce data, the abortion data are in 10-year age groups for ages 30-39 and 40-49, which eliminates important sources of variation in the sex ratio. This reduced variation increases the imprecision of the estimates and is compounded by the probable underreporting of abortion deaths. If the true relationship between sex ratios and abortion deaths in rural areas is negative, as suggested by these results, this likely reflects higher abortion rates for women facing lower sex ratios, rather than worse medical care resulting in higher death rates, as there is little reason to think the quality of medical care varies by age group within regions.

To summarize, the results indicate that women and men who faced low sex ratios were less likely to marry and more likely to divorce. Overall birth rates and marital birth rates were lower as well, while nonmarital births increased. The share of marriages with a large age gap between bride and groom increased, and the evidence is suggestive that rural abortions may have increased as well.

\section{Robustness checks and additional evidence}

\section{a. Robustness checks}

Table 5a presents regressions which test the sensitivity of the results to the inclusion of controls for large region interacted with birth cohort fixed effects. Table $5 \mathrm{~b}$ examines whether 
differences in female labor supply or health are a confounding factor for some of the results. ${ }^{16}$

Table 5a replaces the region-specific cohort trends with an interaction between large

region dummies and year of birth for each of the 11 large regions in Russia. These large region $\times$ year of birth dummies absorb large region-specific shocks which also vary by age group. While most of the results are similar to those in Tables 2, 3 and 4, one notable difference is that the impact of the sex ratio on the male proportion married (column 2) becomes statistically insignificant for the 'all' and urban populations, and is negative and statistically significant for the rural population - similar to the results for men in Table $2 \mathrm{a}$ without the region-specific cohort trends - indicating that male marriage probabilities are particularly sensitive to the inclusion or exclusion of these cohort trends.

As argued previously, an omitted variable that would bias the results would have to vary by birth year in a way similar to that of the sex ratio. One variable that might fit this criteria is female labor supply: due to the shortage of male workers during the war, perhaps women were pulled into the labor force (and remained in it) in a way that mimicked the sex ratio. ${ }^{17}$ While this seems unlikely - it would require a large difference in the change in female employment for women age 25-29 versus women age 35-39, for example - it can be tested using female employment data from the 1959 Census. Table $5 \mathrm{~b}$ produces the results of regressions which

\footnotetext{
${ }^{16}$ Online Appendix Table 3 shows results using different definitions of the sex ratio. For most results the statistical significance of the sex ratio coefficient is unchanged, although the coefficient is smaller in magnitude the more narrowly the sex ratio is defined.

${ }^{17}$ Goldin \& Olivetti (2013) show that female labor force participation in the U.S. increased for more educated women due to World War II. The female labor force participation rate in the USSR was 47.3 percent in 1939 and 48.1 percent in 1950, suggesting a minor impact of World War II on female labor force participation (Ofer \& Vinokur, 1985).
} 
include the female employment to population ratio as a control. ${ }^{18}$ For most outcomes the magnitude and statistical significance of the Sex Ratio coefficient is similar to those of the original specification, indicating that changing female labor supply does not explain the results.

Another possible omitted variable is health status: women in regions and cohorts most affected by the destruction of the war may have suffered greater health shocks through exposure to hunger, trauma and disease; poor health status could in turn reduce one's attractiveness on the marriage market and reduce fecundity. ${ }^{19}$ The lasting health impact of exposure to hunger and trauma from World War II in Europe is clearly evident (Kesternich et al., 2014), suggesting that variations in health status by age and region caused by war exposure could explain some of the results. The best available proxy for health status is age-specific death rates (calculated from deaths by 5 -year age group in the archival data) which should reflect any differing health effects of exposure to war by region and cohort. Including the female age-specific death rate as a control in the regressions, the sign on this variable is generally as expected (e.g., negative in the birth rate regressions) but is usually statistically insignificant. As shown in Table 5b, the coefficient on Sex Ratio is little changed by the inclusion of this proxy for health status. When both female employment and age-specific death rates are included in the regressions, the results are nearly unchanged from those in Table 5b (results shown in Online Appendix Table 4).

\footnotetext{
${ }^{18}$ Note that female employment is an outcome variable, i.e. is predicted to be related to the sex ratio (e.g, Angrist, 2002) and technically should not be included in the regressions as a control variable. When the female employment to population ratio is regressed on the sex ratio and controls, the coefficient on Sex Ratio is statistically insignificant.

${ }^{19}$ I thank a referee for suggesting this possible source of omitted variable bias.
} 


\section{b. Additional evidence: Belarus and Ukraine}

The previous results provide insight into the impact of unbalanced sex ratios on marital status, birth rates, and other outcomes at one point in time. This section uses 1999 and 2001 Census data for Belarus and Ukraine, respectively, to provide retrospective information on possible longer-term consequences of male scarcity, such as completed fertility, childlessness, and the probability of ever marrying. ${ }^{20}$ Ukraine and Belarus are demographically similar to Russia: for women born in 1915-1941, average completed fertility was 2.30 children in Belarus, 1.97 in Ukraine, and 2.04 in Russia (Online Appendix Table 5; Scherbov \& Van Vianen, 2001); the proportion of these women who never married was .052, .046, and .043 in Belarus, Ukraine, and Russia, respectively. In addition, the impact of World War II on the male population was similar in these republics: the sex ratio for the cohort most affected by the war, women age 3539 in 1959, was .627 in Russia, .631 in Ukraine, and .648 in Belarus (Online Appendix Table 1). Given these similarities, the Census results for Ukraine and Belarus may provide a reasonable indication of the long-term consequences of male scarcity for Russian women. One should note, however, that the results for these outcomes are more susceptible to endogenous migration than the 1959 outcomes. Moreover, healthier women are likely over-represented in the Census, as the respondents comprise women age 57 to 86 . If healthier women were more likely to marry and were more fertile, the results may understate the effects of male loss on these outcomes.

Descriptive statistics for the combined Censuses indicate completed fertility of 2.02 children on average for this cohort, with 4.7 percent never marrying and 10.4 percent remaining childless (Table 6). The regressions use the same specification and sex ratio definition as previously; the microdata are collapsed by region to be comparable to the region-level analysis of

\footnotetext{
${ }^{20}$ Data are from IPUMS International (http://international.ipums.org/international).
} 
the Russian data. All three outcomes - completed fertility and the probability of marriage and childlessness - have the expected signs and are statistically significant at the 5 percent level or less (Table 7). A two-standard deviation decrease in the sex ratio is associated with a decrease in number of children ever born of .15 to .20 child, depending on how the sex ratio is calculated, or a 7.5 to 10 percent decrease in completed fertility. The probability of being childless increased by .031 points or a nearly 30 percent increase in the average rate. The probability of never marrying increased by .034 points with a two-standard deviation decrease in sex ratio, a large effect given the .047 share of women who never married in this cohort. In sum, the results confirm that the effects of the large loss of male life were long-lasting, leading to decreased fertility, lower probability of ever marrying and higher probability of childlessness. The magnitude of the effect on completed fertility is relatively small in light of the scale of male losses, perhaps due to the pronatalist policy that promoted out of wedlock births. ${ }^{21}$

\section{$\underline{\text { V. Conclusion }}$}

World War II exacted a devastating toll on the Soviet population. Tens of millions of people died, mostly men, leaving behind a cohort of women who survived but faced highly unfavorable conditions in the marriage market and within marriage. The results presented in this paper suggest that the effects of the war impacted these women's lives for decades, leading to lower rates of marriage and fertility, and higher rates of out of wedlock births and divorce in urban areas, than would have been the case absent the war. These effects were likely exacerbated

\footnotetext{
${ }^{21}$ Regressions using the Russian Longitudinal Monitoring Survey test whether low sex ratios increased the number of abortions a woman had in her lifetime. The relationship between the sex ratio and abortions is negative, as predicted, but the sample size is small and the results are sensitive to specification (see Online Appendix Tables 7 and 8).
} 
by an institutional environment that encouraged nonmarital births and increased the cost of binding commitments through marriage, particularly for men. While the 1944 Family Code appears to have increased marital instability and reduced registered marriage for both men and women, it nevertheless may have benefitted women by reducing the stigma of unmarried motherhood and creating a financial and social environment in which unmarried women had a realistic option of having a child.

The shock to sex ratios in the Soviet Union due to World War II was among the largest experienced by any country in the twentieth century. In this sense, the effect on Russian women and men was unique and arguably not relevant to other countries or time periods. Yet highly unbalanced sex ratios characterize many populations - whether due to wars, immigration and emigration, or son preference, among other reasons - and therefore this analysis can shed light on the effects of sex ratio imbalance in other contexts. In particular, the results support the conclusion of a growing body of evidence that sex ratios matter for marital and fertility outcomes, both on the marriage market itself and within marriage. The experience of the Soviet Union, with its backdrop of radically changing divorce and child support laws between the two World Wars, also highlights that the institutional context of the sex ratio imbalance matters for determining both the size and direction of its impact on marriage markets and family formation. 


\section{$\underline{\text { References }}$}

Abramitzky, Ran, Adeline Delavande and Luis Vasconcelos, "Marrying Up: The Role of Sex Ratio in Assortative Matching," American Economic Journal: Applied Economics 3 (2011), 124-157.

Acemoglu, Daron, Tarek A. Hassan and James A. Robinson, "Social Structure and Development: A Legacy of the Holocaust in Russia," Quarterly Journal of Economics 126 (2011), 895946.

Anderson, Barbara A., Kalev Katus, and Brian D. Silver, "Developments and Prospects for Population Statistics in Countries of the Former Soviet Union," Population Index 60 (1994), 4-20.

Anderson, Barbara A. and Brian D. Silver, "Infant Mortality in the Soviet Union: Regional Differences and Measurement Issues," Population and Development Review 12 (1986), $705-738$.

Andreev, E., L. Darskii and T. Kharkova, “Otsenka lyudskikh poter' v period Velikoi Otechestvennoi voiny,” Vestnik statistiki 10 (1990), 25-27.

Andreev, E. M., L. E. Darskii and T. L. Kharkova, Naselenie Sovetskogo Soyuza: 1922-1991 (Moscow, 1993).

Angrist, Josh, "How Do Sex Ratios Affect Marriage and Labor Markets? Evidence from America's Second Generation," Quarterly Journal of Economics 117 (2002), 997-1038.

Avdeev, Alexandre and Alain Monnier, "Marriage in Russia: A Complex Phenomenon Poorly Understood," Population: An English Selection 12 (2000), 7 - 49.

Barber, John and Mark Harrison, The Soviet Home Front, 1941-1945: A Social and Economic History of the USSR in World War II (London and New York: Longman Group, 1991).

Becker, Gary S., “A Theory of Marriage: Part I,” Journal of Political Economy 81 (1973), 813846.

Becker Gary S., “A Theory of Marriage: Part II," Journal of Political Economy 82 (1974), S11S26.

Becker, Gary S., A Treatise on the Family (Cambridge: Harvard University Press, 1981).

Bertrand, Marianne, Esther Duflo and Sendhil Mullainathan, "How Much Should We Trust Differences-in-Differences Estimates?" Quarterly Journal of Economics 119 (2004), 249275.

Bethmann, Dirk and Michael Kvasnicka, "World War II, Missing Men and Out of Wedlock 
Childbearing," The Economic Journal 123 (2013), 162-194.

Charles, Kerwin Kofi and Ming Ching Luoh, "Male Incarceration, the Marriage Market, and Female Outcomes," this REVIEW 92 (2010), 614-627.

Chiappori, Pierre-André, Bernard Fortin, and Guy Lacroix, "Marriage Market, Divorce Legislation, and Household Labor Supply," Journal of Political Economy 110 (2002), 3772 .

Edlund, Lena, Hongbin Li, Junjian Yi and Junsen Zhang, "Sex Ratios and Crime: Evidence from China," this REVIEW 95 (2013), 1520-1534.

Ellman, Michael and S. Maksudov, "Soviet Deaths in the Great Patriotic War," Europe-Asia Studies 46 (1994), 671-680.

Francis, Andrew M., "Sex Ratios and the Red Dragon: Using the Chinese Communist Revolution to Explore the Effect of the Sex Ratio on Women and Children in Taiwan," Journal of Population Economics 24 (2011), 813-837.

Glantz, David M., Stumbling Colossus: The Red Army on the Eve of World War (Kansas: University Press of Kansas, 1998).

Glantz, David M., Colossus Reborn: The Red Army at War, 1941-1943 (Kansas: University Press of Kansas, 2005).

Goldin, Claudia and Claudia Olivetti, "Shocking Labor Supply: A Reassessment of the Role of World War II on Women's Labor Supply," American Economic Review Papers \& Proceedings 10 (2013), 257-262.

Goskomstat of Russia, Naselenie Rossii za 100 let (1897 - 1997) (Moscow, 1998).

Grosjean, Pauline and Rose Khattar, “It’s Raining Men! Hallelujah?” UNSW Business School Research Paper No. 2014-29C, 2014.

Grossbard-Shechtman, Shoshana, On the Economics of Marriage: A Theory of Marriage, Labor, and Divorce (Boulder, CO: Westview Press, 1993).

Guttentag, Marcia and Paul F. Secord, Too Many Women? The Sex Ratio Question (Beverly Hills: Sage Publications, 1983).

Heer, David M., "Three Issues in Soviet Population Policy," Population and Development Review 3 (1977), 229-252.

Ivakhnyuk, Irina, "The Russian Migration Policy and Its Impact on Human Development: The Historical Perspective,” Human Development Research Paper 2009/14, UNDP, 2009. 
Kesternich, Iris, Bettina Siflinger, James P. Smith and Joachim K. Winter, "The Effects of World War II on Economic and Health Outcomes Across Europe," this REVIEW 96 (2014), 103118.

Krivosheev, G. F., V. M Andronikov, P. D. Burikov, V. V. Gurkin, A. I. Kruglov, Ye. I. Rodionov, and M. V. Filimoshin, Soviet Casualties and Combat Losses in the Twentieth Century (London: Greenhill Books, 1997).

LaFortune, Jeanne, "Making Yourself Attractive: Pre-Marital Investments and the Returns to Education in the Marriage Market," American Economic Journal: Applied Economics 5 (2013), 151-178.

Mechoulan, Stéphane, "The External Effects of Black Male Incarceration on Black Females," Journal of Labor Economics 29 (2011), 1-35.

Moskoff, William, “Divorce in the USSR,” Journal of Marriage and Family 45 (1983), 419-425.

Nakachi, Mie, "Population, Politics and Reproduction: Late Stalinism and its Legacy," in Juliane Fürst, ed., Late Stalinist Russia: Society Between Reconstruction and Reinvention (London: Routledge, 2006), 23-45.

Nakachi, Mie, Replacing the Dead: The Politics of Reproduction in the Postwar Soviet Union, 1944-1955, Ph.D. dissertation, University of Chicago, 2008.

Newell, Colin, Methods and Models in Demography (West Sussex, England: John Wiley \& Sons), 1994.

Ofer, Gur and Aaron Vinokur, "Work and Family Roles of Soviet Women: Historical Trends and Cross-Section Analysis," Journal of Labor Economics 3 (1985), S328-S354.

Rowland, Richard H., "Regional Population Trends in the Former USSR, 1939-1951, and the Impact of World War II," Carl Beck Papers in Russian \& East European Studies, Number 1207, Center for Russian and East European Studies, University of Pittsburgh, 1997.

Scherbov, Sergei and Harrie Van Vianen, "Marriage and Fertility in Russia of Women Born Between 1900 and 1960: A Cohort Analysis," European Journal of Population 17 (2001), 281-294.

Solon, Gary, Steven J. Haider and Jeffrey M. Wooldridge, "What Are We Weighting For?" Journal of Human Resources 50 (2015), 301-16.

Tsentral'noe Statisticheskoe Upravelenie, Itogi vsesoyuznoi perepisi naseleniya 1959 goda: RSFSR (Moscow: Gosstatizdat, 1963).

Tsentral'noe statisticheskoe upravlenie SSSR, Vsesoiuznaia perepis naseleniia godu 1926 (Moscow, 1928-1935) 
Wei, Shang-Jin and Xiaobo Zhang, "The Competitive Saving Motive: Evidence from Rising Sex Ratios and Savings Rates in China," Journal of Political Economy 119 (2011), 511-564. 
Fig. 1 Sex Ratio by Single Year of Age, Russia, 1959

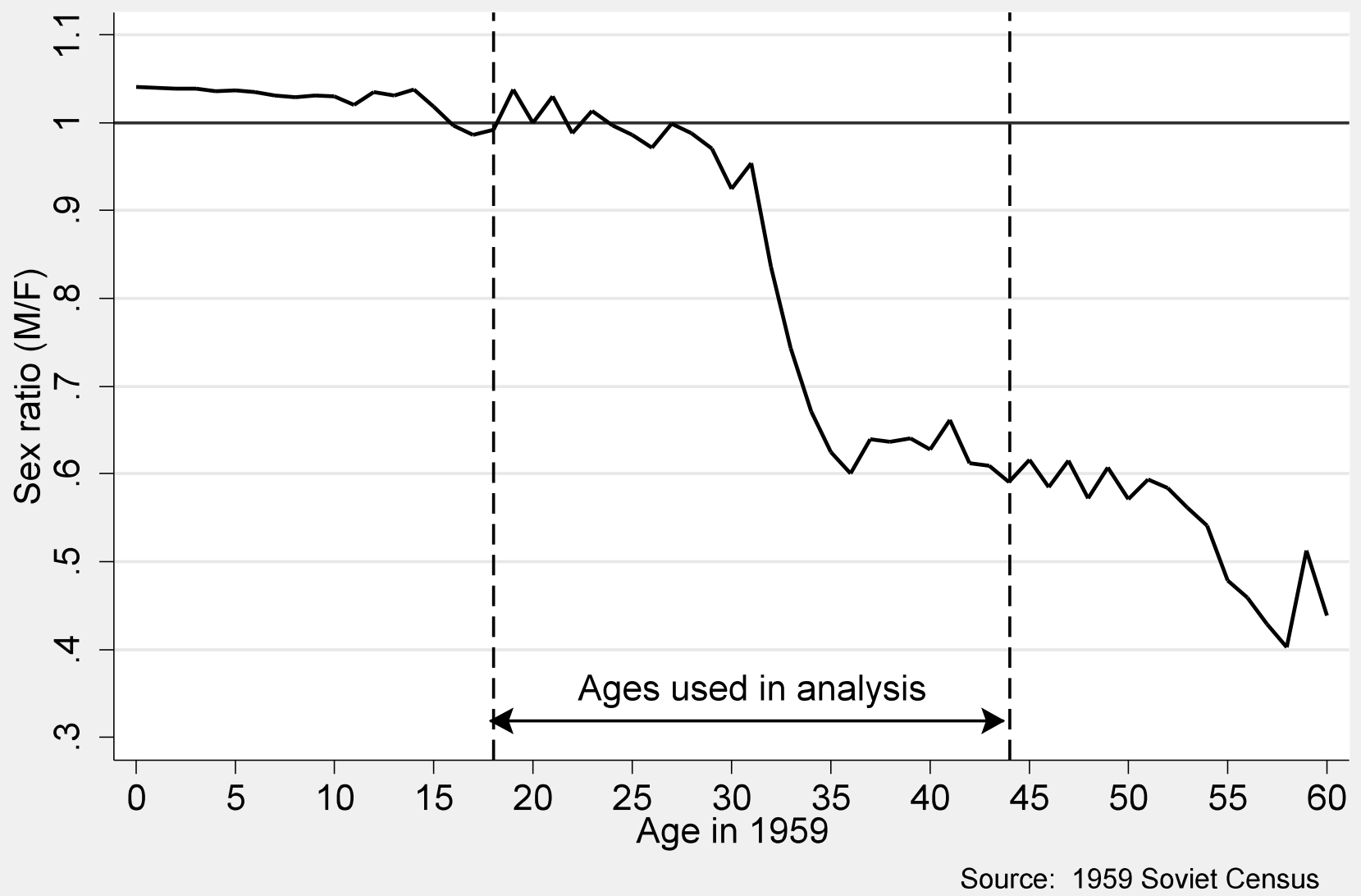


Fig. 2 Sex Ratios by Russian Region, Ages 25-29 and 35-39, 1959

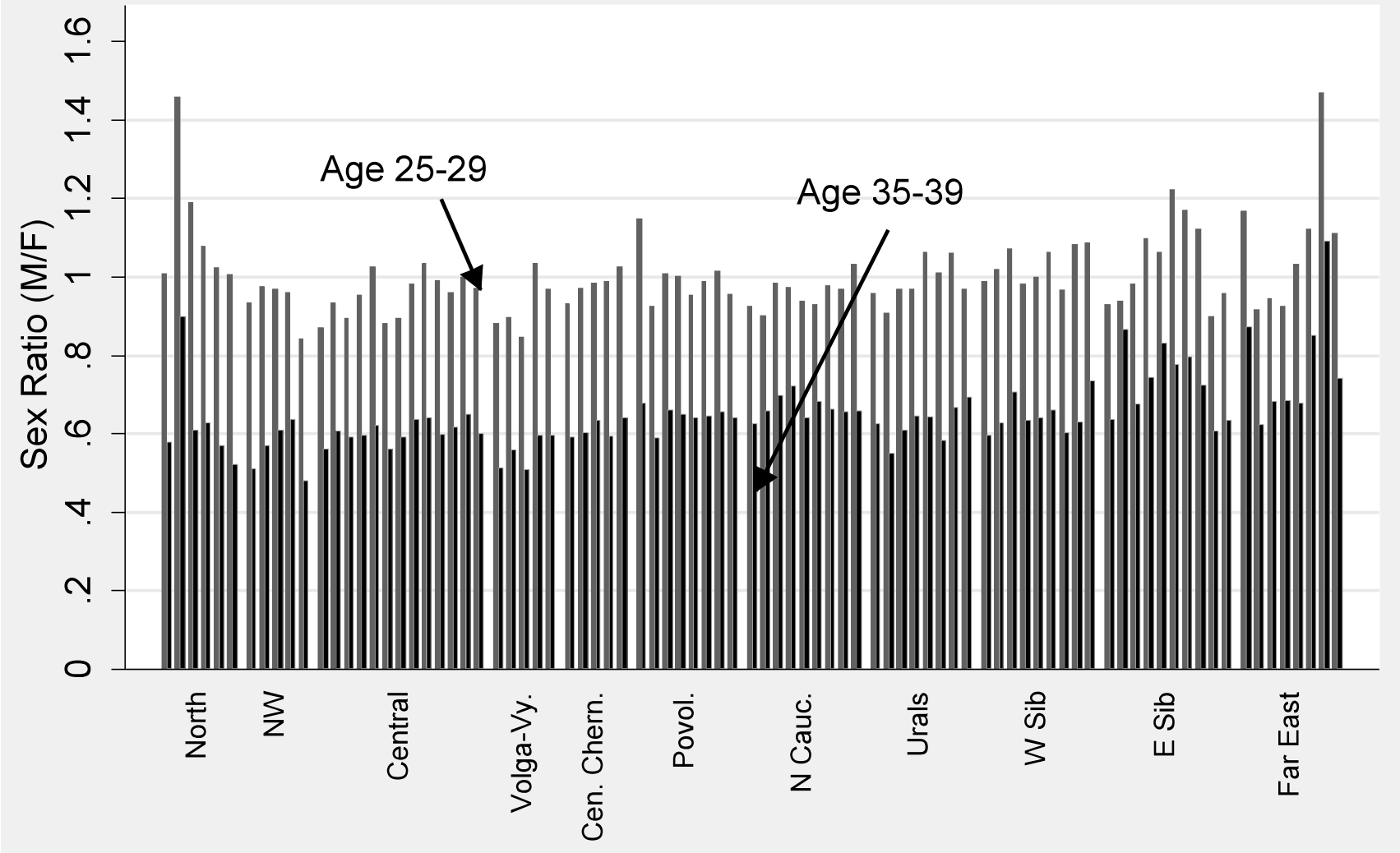

Sex ratios here are: (men 25-29)/(women 25-29) and (men35-39)/(women 35-39). Source: 1959 Soviet Census. 
Fig. 3 Mean Age at First Marriage and Completed Fertility by Year of Birth, Russian Women

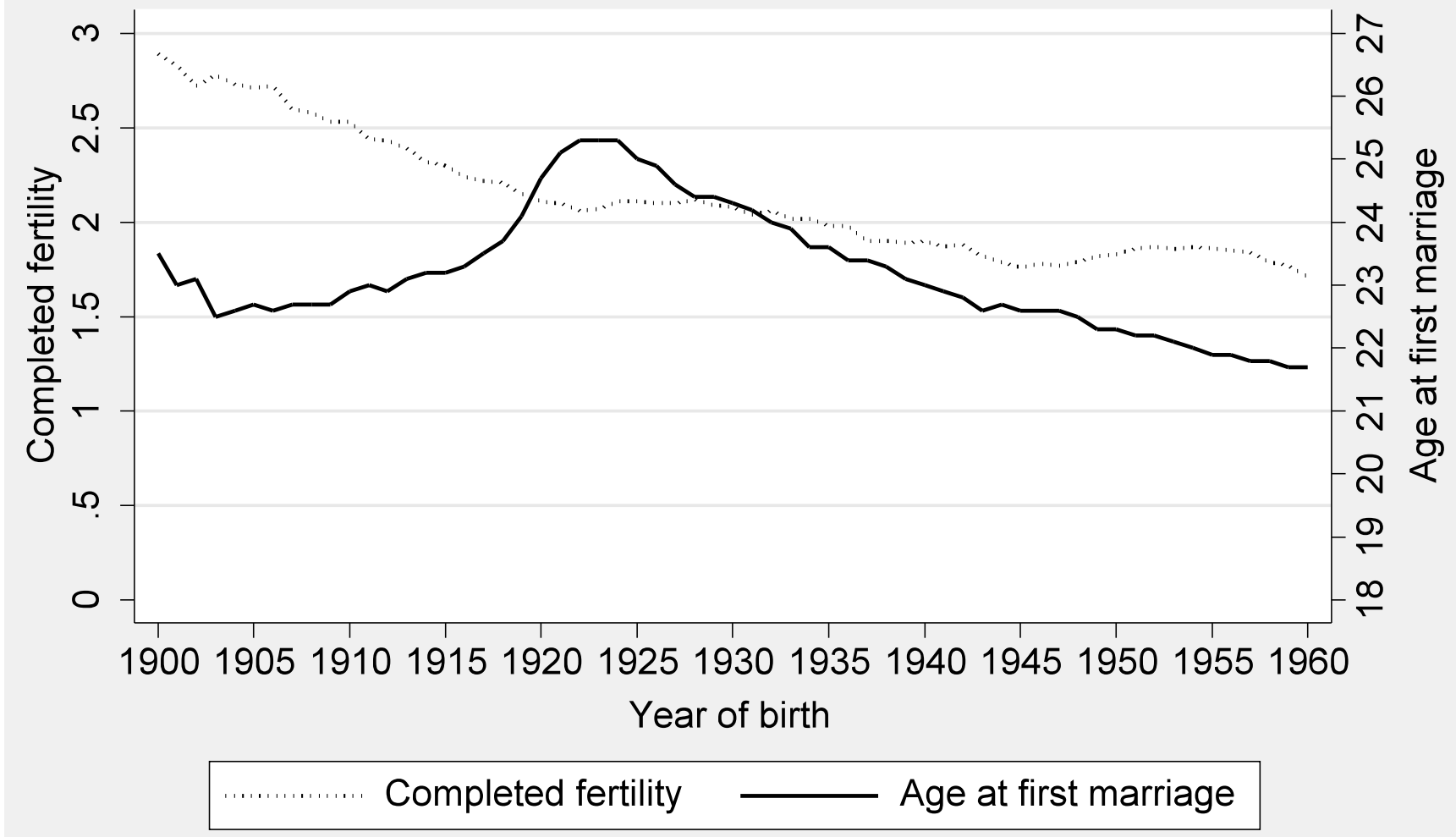

Source: Scherbov and Van Vianen 2001. 


\section{Table 1. Summary Statistics, 1959 Russian Census and Vital Statistics}

(weighted by population)

$$
\underline{\text { Mean }} \underline{\text { SD }} \text { Min. Max. } \quad \underline{N}
$$

AGE 18 - 44, YEAR OF BIRTH 1915-1941; DATA BY SINGLE YEAR OF AGE:

$\begin{array}{crrrrr}\text { Sex ratio, all pop. } & .796 & .168 & .447 & 1.950 & 2025 \\ \text { Urban pop. } & .810 & .149 & .470 & 1.995 & 2025 \\ \text { Rural pop. } & .777 & .199 & .408 & 1.761 & 1971 \\ \text { Proportion married: } & & & & & \\ \text { Women, all pop. } & .618 & .201 & .034 & .893 & 2025 \\ \text { Urban } & .620 & .218 & .027 & .899 & 2025 \\ \text { Rural } & .617 & .181 & .048 & .918 & 1971 \\ \text { Men, all pop. } & .648 & .353 & .011 & .984 & 2025 \\ \text { Urban } & .641 & .352 & .006 & .991 & 2025 \\ \text { Rural } & .658 & .355 & .013 & .987 & 1971 \\ \text { Births per 1,000 women at each age: } & & & & \\ \text { All } & 100.6 & 60.9 & .680 & 305.7 & 2025 \\ \text { Urban } & 81.2 & 52.6 & 0 & 313.5 & 2025 \\ \text { Rural } & 126.5 & 71.3 & 2.8 & 381.2 & 1971\end{array}$

AGE 16- 44, YEAR OF BIRTH 1915-1943; DATA BY 5-YEAR AGE GROUP (16-19, 20-24, 25-29, 3034, 35-39, AND 40-44:

$\begin{array}{llllll}\text { Sex ratio, all pop. } & .809 & .162 & .459 & 1.700 & 437\end{array}$

$\begin{array}{llllll}\text { Urban pop. } & .819 & .142 & .488 & 1.720 & 437\end{array}$

$\begin{array}{llllll}\text { Rural pop. } & .796 & .195 & .419 & 1.661 & 425\end{array}$

Marital birth rate (births per 1,000 married women):

$\begin{array}{lccccc}\text { All } & 185.5 & 129.1 & 4.1 & 471.8 & 437 \\ \text { Urban } & 171.3 & 137.9 & 4.1 & 506.9 & 437 \\ \text { Rural } & 206.2 & 121.2 & 13.4 & 560.7 & 425\end{array}$

Nonmarital birth rate (nonmarital births per 1,000 unmarried women):

$\begin{array}{llllll}\text { All } & 43.2 & 36.4 & 0.9 & 257.5 & 437 \\ \text { Urban } & 31.5 & 27.7 & 0.9 & 144.9 & 437 \\ \text { Rural } & 58.9 & 49.2 & 0.2 & 340.2 & 425\end{array}$

Share of out of wedlock births:

$\begin{array}{llllll}\text { All } & .156 & .065 & .046 & .609 & 437 \\ \text { Urban } & .140 & .055 & .047 & .425 & 437 \\ \text { Rural } & .170 & .076 & .002 & .795 & 425\end{array}$

Proportion of marriages with 11+ year age gap between bride and groom (ages 16-49): ${ }^{\mathrm{a}}$

$\begin{array}{llllll}\text { All } & .071 & 071 & 0.0 & .355 & 525 \\ \text { Urban } & .068 & .068 & 0.0 & .305 & 525 \\ \text { Rural } & .076 & .078 & 0.0 & .460 & 511\end{array}$


Divorce rate (divorces per 1,000 married population) (ages 18-49): ${ }^{\text {b }}$

$\begin{array}{lrrrrr}\text { All } & 8.8 & 5.9 & 0.0 & 30.4 & 375 \\ \text { Urban } & 13.1 & 7.5 & 0.0 & 46.4 & 375 \\ \text { Rural } & 3.4 & 3.2 & 0.0 & 20.9 & 365\end{array}$

Deaths due to abortion per 100 births (ages 16-49): ${ }^{\text {c }}$

$\begin{array}{llllll}\text { All } & .108 & .114 & 0.0 & .917 & 365 \\ \text { Urban } & .121 & .200 & 0.0 & 2.37 & 360 \\ \text { Rural } & .104 & .122 & 0.0 & .778 & 345\end{array}$

Female employment to population ratio:

$\begin{array}{llllll}\text { All } & .733 & .088 & .363 & .905 & 450 \\ \text { Urban } & .710 & .107 & .311 & .920 & 450 \\ \text { Rural } & .764 & .083 & .414 & .950 & 438\end{array}$

Female age-specific death rate (deaths per 1,000 population):

$\begin{array}{lccccc}\text { All } & 1.7 & 0.7 & 0.5 & 9.4 & 437 \\ \text { Urban } & 1.5 & 0.7 & 0.3 & 12.4 & 437 \\ \text { Rural } & 1.9 & 0.8 & 0.0 & 16.7 & 425\end{array}$

${ }^{\mathrm{a}}$ Data are for age groups 16-19, 20-24, 25-29, 30-34, 35-39, 40-44, and 45-49.

${ }^{b}$ Data are for age groups 18-19, 20-24, 25-29, 30-39, and 40-49.

${ }^{\mathrm{c}}$ Data are for age groups 16-19, 20-24, 25-29, 30-39, and 40-49. 


\section{Table 2a. Stacked regressions by single year of birth, 1959 Russian Census Year of birth 1915-1941 (age 18-44 in 1959)}

\begin{tabular}{lllll}
\hline \hline \multirow{2}{*}{ Dependent variable } & \multicolumn{5}{c}{ Pomen } \\
\cline { 2 - 6 } & OLS & WLS & OLS & WLS \\
& $(1)$ & $(2)$ & $(3)$ & $(4)$ \\
\hline All population & $.149^{* * *}$ & $.150^{* * *}$ & $.201^{* * *}$ & $.187^{* * *}$ \\
$(\mathrm{~N}=2,025)$ & $(.027)$ & $(.045)$ & $(.040)$ & $(.055)$ \\
\hline Urban population & $.111^{* * *}$ & $.104^{* *}$ & $.229^{* * *}$ & $.213^{* * *}$ \\
$\quad \mathrm{~N}=2,025)$ & $(.021)$ & $(.040)$ & $(.027)$ & $(.032)$ \\
\hline Rural population & $.136^{* * *}$ & .093 & .096 & .118 \\
$(\mathrm{~N}=1,971)$ & $(.045)$ & $(.066)$ & $(.082)$ & $(.108)$ \\
\hline \hline & & \multicolumn{3}{c}{ Men } \\
\hline All population & -.026 & .028 & $.178^{* * *}$ & $.185^{* * *}$ \\
$(\mathrm{~N}=2,025)$ & $(.034)$ & $(.031)$ & $(.049)$ & $(.058)$ \\
\hline Urban population & .018 & $.076^{* *}$ & $.155^{* * *}$ & $.167^{* * *}$ \\
$(\mathrm{~N}=2,025)$ & $(.025)$ & $(.033)$ & $(.048)$ & $(.051)$ \\
\hline Rural population & $-.075^{* *}$ & $-.048^{*}$ & $.192^{* * *}$ & $.153^{* *}$ \\
$\quad \mathrm{~N}=1,971)$ & $(.032)$ & $(.027)$ & $(.064)$ & $(.063)$ \\
\hline \hline Oblast and birth cohort FE & Yes & Yes & Yes & Yes \\
Oblast-specific linear cohort trend & No & No & Yes & Yes \\
\hline \hline
\end{tabular}

Each cell shows the coefficient on Sex Ratio from a separate regression. Sex ratio is the number of men from -2 to +10 years older than women of a given age, divided by the number of women in the same age range. WLS: weighted by population. Regressions control for $\log$ (male pop.) (for women) or $\log ($ female pop.) (for men) and for $\%$ urban ('all population' regressions). Standard errors corrected for clustering within oblasts. ${ }^{* *} \mathrm{p}<0.01,{ }^{*} \mathrm{p}<0.05$, and ${ }^{*} \mathrm{p}<0.1$. 
Table 2b. Stacked OLS regressions by 5-year age group, 1926 and 1959 Russian Censuses, ages 18-44

\begin{tabular}{lcccc}
\hline \hline Dependent variable & \multicolumn{4}{c}{ Proportion married } \\
\cline { 2 - 5 } & \multicolumn{2}{c}{1926 Census } & \multicolumn{2}{c}{ 1959 Census } \\
\cline { 2 - 5 } & Women & Men & Women & Men \\
\hline All population & $(1)$ & $(2)$ & $(3)$ & $(4)$ \\
\hline Urban population & .022 & .105 & $.223^{* * *}$ & $.189 * * *$ \\
& $(.101)$ & $(.139)$ & $(.051)$ & $(.077)$ \\
\hline Rural population & .043 & .031 & $.227^{* * *}$ & $.168^{* *}$ \\
& $(.040)$ & $(.071)$ & $(.039)$ & $(.072)$ \\
\hline \hline Oblast and birth cohort FE & .040 & .093 & .144 & $.174^{*}$ \\
Oblast-specific linear cohort trend & $(.189)$ & $(.176)$ & $(.130)$ & $(.105)$ \\
\hline \hline
\end{tabular}

Each cell shows the coefficient on Sex Ratio from a separate regression. Sex ratio is the number of men from -2 to +10 years older than women of a given age range, divided by the number of women in the same age range. Regressions control for $\log$ (male pop.) (for women) or $\log$ (female pop.) (for men) and for \% urban ('all population' regressions). Standard errors corrected for clustering within oblasts. $\mathrm{N}=660$ for 1926 Census regressions for 'all' population; $\mathrm{N}=593$ for urban; $\mathrm{N}=623$ for rural. $\mathrm{N}=450$ for 1959 Census regressions for 'all' and 'urban' populations'; N=438 for rural population. Source of 1926 data: Tsentral'noe statisticheskoe upravlenie SSSR (Moscow, 1928-1935). ***p $<0.01,{ }^{* *} \mathrm{p}<0.05$, and $* \mathrm{p}<0.1$. 
Table 3. Stacked regressions by single year of birth, 1959 Russian Census and Vital Statistics Data Year of birth 1915-1941 (age 18-44 in 1959)

\begin{tabular}{|c|c|c|c|c|c|c|}
\hline \multirow[t]{2}{*}{ Dependent variable } & \multicolumn{4}{|c|}{ Births per 1000 women: } & \multicolumn{2}{|c|}{$\log ($ birth rate): } \\
\hline & $\begin{array}{l}\text { OLS } \\
(1)\end{array}$ & $\begin{array}{l}\text { WLS } \\
(2)\end{array}$ & $\begin{array}{l}\text { OLS } \\
(3)\end{array}$ & $\begin{array}{l}\text { WLS } \\
(4)\end{array}$ & $\begin{array}{c}\text { OLS } \\
(5)\end{array}$ & $\begin{array}{l}\text { WLS } \\
(6)\end{array}$ \\
\hline $\begin{array}{l}\text { All population } \\
(\mathrm{N}=2,025)\end{array}$ & $\begin{array}{l}22.3 * \\
(12.5)\end{array}$ & $\begin{array}{c}30.5 \\
(22.6)\end{array}$ & $\begin{array}{l}160.7 * * * \\
(28.8)\end{array}$ & $\begin{array}{l}167.1 * * * \\
(43.3)\end{array}$ & $\begin{array}{l}1.47 * * * \\
(.211)\end{array}$ & $\begin{array}{r}.940 \\
(.691)\end{array}$ \\
\hline $\begin{array}{l}\text { Urban population } \\
\qquad(\mathrm{N}=2,025)\end{array}$ & $\begin{array}{c}5.3 \\
(8.6)\end{array}$ & $\begin{array}{c}11.8 \\
(19.7)\end{array}$ & $\begin{array}{l}97.0 * * * \\
(14.0)\end{array}$ & $\begin{array}{l}93.4 * * * \\
(16.7)\end{array}$ & $\begin{array}{l}1.66 * * * \\
(.224)\end{array}$ & $\begin{array}{l}1.15^{* *} \\
(.558)\end{array}$ \\
\hline $\begin{array}{l}\text { Rural population } \\
\qquad(\mathrm{N}=1,971)\end{array}$ & $\begin{array}{c}30.9 \\
(20.7)\end{array}$ & $\begin{array}{c}14.2 \\
(37.8)\end{array}$ & $\begin{array}{l}190.0 * * * \\
(34.2)\end{array}$ & $\begin{array}{c}139.5 \\
(103.5)\end{array}$ & $\begin{array}{l}1.53 * * * \\
(.266)\end{array}$ & $\begin{array}{l}1.39 * * * \\
(.532)\end{array}$ \\
\hline Oblast and birth cohort FE & Yes & Yes & Yes & Yes & Yes & Yes \\
\hline Oblast-specific linear cohort trend & No & No & Yes & Yes & Yes & Yes \\
\hline
\end{tabular}

Each cell shows the coefficient on Sex Ratio from a separate regression. Sex ratio is the number of men from -2 to +10 years older than women of a given age, divided by the number of women in the same age range. WLS: weighted by population. Regressions control for $\log ($ male pop.) and $\%$ urban population ('all population' regressions). Standard errors corrected for clustering within oblasts. ${ }^{* *} \mathrm{p}<0.01,{ }^{*} \mathrm{p}<0.05$, and ${ }^{*} \mathrm{p}<0.1$. 
Table 4. Stacked regressions by 5-year age group, 1959 Russian Census and Vital Statistics Data Year of birth 1915-1943 (age 16-44 in 1959)

\begin{tabular}{|c|c|c|c|c|c|c|c|c|c|c|c|c|}
\hline \multirow[t]{2}{*}{$\begin{array}{l}\text { Dep. } \\
\text { variable }\end{array}$} & \multicolumn{2}{|c|}{ Marital birth rate } & \multicolumn{2}{|c|}{ Nonmarital birth rate } & \multicolumn{2}{|c|}{$\begin{array}{l}\text { Share of out of } \\
\text { wedlock births }\end{array}$} & \multicolumn{2}{|c|}{$\begin{array}{c}\text { Prop. of marriages } \\
\text { with } 11+\text { year age gap }\end{array}$} & \multicolumn{2}{|c|}{ Divorce rate } & \multicolumn{2}{|c|}{$\begin{array}{l}\text { Deaths due to } \\
\text { abortion per } \\
100 \text { births }\end{array}$} \\
\hline & $\begin{array}{l}\text { OLS } \\
(1) \\
\end{array}$ & $\begin{array}{l}\text { WLS } \\
(2)\end{array}$ & $\begin{array}{l}\text { OLS } \\
(3)\end{array}$ & $\begin{array}{l}\text { WLS } \\
(4)\end{array}$ & $\begin{array}{l}\text { OLS } \\
(5)\end{array}$ & $\begin{array}{l}\text { WLS } \\
(6)\end{array}$ & $\begin{array}{l}\text { OLS } \\
(7) \\
\end{array}$ & $\begin{array}{l}\text { WLS } \\
(8)\end{array}$ & $\begin{array}{l}\text { OLS } \\
(9) \\
\end{array}$ & $\begin{array}{l}\text { WLS } \\
(10)\end{array}$ & $\begin{array}{l}\text { OLS } \\
(11) \\
\end{array}$ & $\begin{array}{l}\text { WLS } \\
(12) \\
\end{array}$ \\
\hline All pop. & $\begin{array}{l}212.6^{* *} \\
(88.9)\end{array}$ & $\begin{array}{l}235.1 * \\
(121.6)\end{array}$ & $\begin{array}{l}-208.7 * * * \\
(47.4)\end{array}$ & $\begin{array}{l}-129.1 \\
(117.6)\end{array}$ & $\begin{array}{l}-.064 \\
(.059)\end{array}$ & $\begin{array}{l}-.144 \\
(.089)\end{array}$ & $\begin{array}{l}-.160 * * * \\
(.044)\end{array}$ & $\begin{array}{l}-.122 * * \\
(.050)\end{array}$ & $\begin{array}{l}-9.4^{*} \\
(5.2)\end{array}$ & $\begin{array}{l}-21.1^{* * *} \\
(8.1)\end{array}$ & $\begin{array}{l}.005 \\
(.341)\end{array}$ & $\begin{array}{l}.336 \\
(.400)\end{array}$ \\
\hline $\begin{array}{l}\text { Urban } \\
\text { pop. }\end{array}$ & $\begin{array}{l}96.8 * * \\
(42.4)\end{array}$ & $\begin{array}{l}83.6 * * \\
(41.6)\end{array}$ & $\begin{array}{l}-170.7 * * * \\
(35.2)\end{array}$ & $\begin{array}{l}-96.9 \\
(83.8)\end{array}$ & $\begin{array}{l}-.090 * \\
(.050)\end{array}$ & $\begin{array}{c}-.144^{* *} \\
(.070)\end{array}$ & $\begin{array}{l}-.157 * * * \\
(.030)\end{array}$ & $\begin{array}{l}-.180 * * * \\
(.036)\end{array}$ & $\begin{array}{l}-9.1 \\
(7.5)\end{array}$ & $\begin{array}{l}-18.7 * * * \\
(6.1)\end{array}$ & $\begin{array}{l}.099 \\
(.554)\end{array}$ & $\begin{array}{c}.447 \\
(.637)\end{array}$ \\
\hline $\begin{array}{l}\text { Rural } \\
\text { pop. }\end{array}$ & $\begin{array}{l}202.3 * * \\
(100.6) \\
\end{array}$ & $\begin{array}{c}149.1 \\
(210.5) \\
\end{array}$ & $\begin{array}{c}-222.4^{* *} \\
(106.6) \\
\end{array}$ & $\begin{array}{c}-334.3^{* *} \\
(150.8) \\
\end{array}$ & $\begin{array}{r}.011 \\
(.044) \\
\end{array}$ & $\begin{array}{l}.034 \\
(.095) \\
\end{array}$ & $\begin{array}{l}-.002 \\
(.114) \\
\end{array}$ & $\begin{array}{r}.138 * \\
(.083) \\
\end{array}$ & $\begin{array}{c}.537 \\
(.422) \\
\end{array}$ & $\begin{array}{c}.624 \\
(.456) \\
\end{array}$ & $\begin{array}{l}-.067 \\
(.048) \\
\end{array}$ & $\begin{array}{l}-.047 \\
(.031) \\
\end{array}$ \\
\hline
\end{tabular}

All regressions include oblast and birth cohort fixed effects, and oblast-specific linear cohort trends. Each cell shows the coefficient on Sex Ratio from a separate regression. Sex ratio is the number of men from -2 to +10 years older than women of a given age range, divided by the number of women in the same age range. WLS: weighted by population. Regressions control for log(male pop.) or $\log$ (pop.) (divorce rate); 'all population' regressions control for $\%$ urban population. Standard errors corrected for clustering within oblasts. See Table 1 for sample sizes and age groups for each dependent variable. $* * * p<0.01, * * p<0.05$, and $* p<0.1$. 


\section{Table 5a. Robustness Checks}

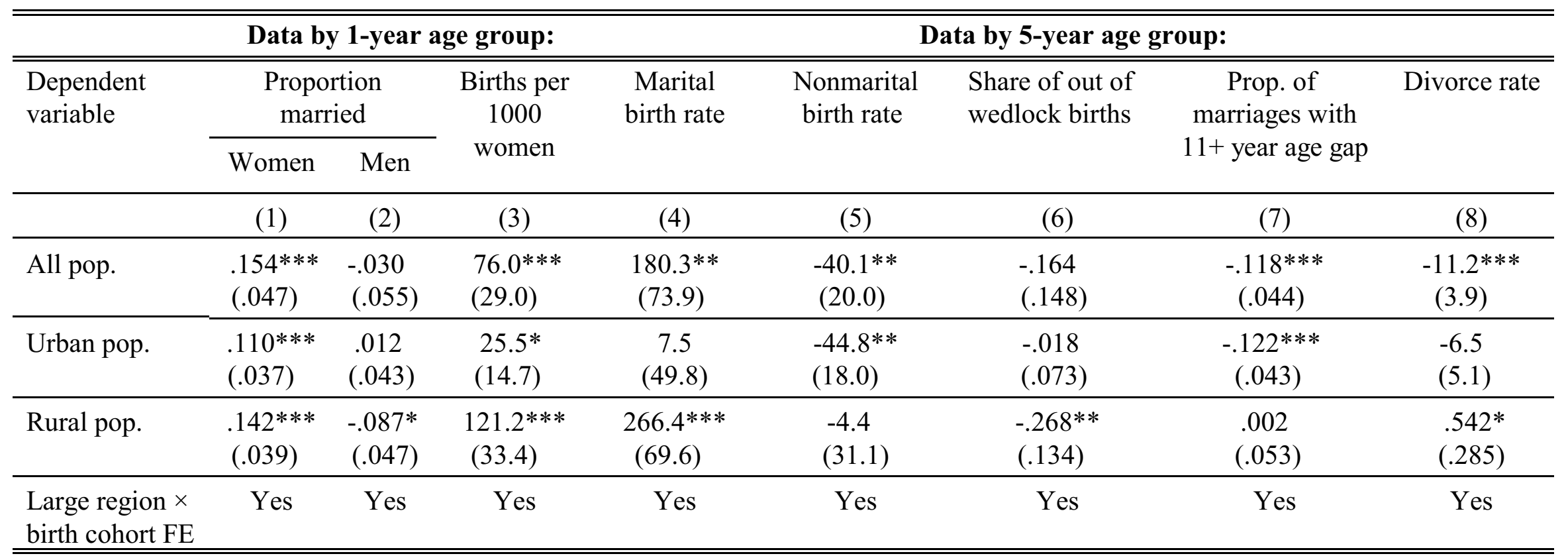

All regressions include oblast and birth cohort fixed effects. Each cell shows the coefficient on Sex Ratio from a separate regression. Sex ratio is the number of men from -2 to +10 years older than women of a given age, divided by the number of women in the same age range. Regressions control for $\log$ (male pop.) or $\log$ (female pop.) and \% urban population (for 'all population' regressions). Standard errors corrected for clustering within oblasts. See Table 1 for sample sizes and age groups. $* * * p<0.01, * * p<0.05$, and $* p<0.1$. 
Table 5b. Robustness Checks (data by 5-year age group)

\begin{tabular}{|c|c|c|c|c|c|c|c|c|c|c|}
\hline \multirow[t]{2}{*}{ Dependent variable } & \multicolumn{2}{|c|}{ Marital birth rate } & \multicolumn{2}{|c|}{ Nonmarital birth rate } & \multicolumn{2}{|c|}{$\begin{array}{l}\text { Share of out of } \\
\text { wedlock births }\end{array}$} & \multicolumn{2}{|c|}{ Divorce rate } & \multicolumn{2}{|c|}{$\begin{array}{c}\text { Deaths due to } \\
\text { abortion per } 100 \\
\text { births }\end{array}$} \\
\hline & $(1)$ & $(2)$ & $(3)$ & $(4)$ & $(5)$ & $(6)$ & $(7)$ & $(8)$ & $(9)$ & $(10)$ \\
\hline All population & $\begin{array}{l}215.6^{* *} \\
(93.0)\end{array}$ & $\begin{array}{l}214.9 * * \\
(90.8)\end{array}$ & $\begin{array}{l}-205.9 * * * \\
(48.7)\end{array}$ & $\begin{array}{l}-157.3 * * * \\
(52.2)\end{array}$ & $\begin{array}{l}-.063 \\
(.059)\end{array}$ & $\begin{array}{l}-.092 \\
(.062)\end{array}$ & $\begin{array}{l}-9.2 * \\
(5.2)\end{array}$ & $\begin{array}{c}-10.7 * * \\
(5.3)\end{array}$ & $\begin{array}{l}.016 \\
(.324)\end{array}$ & $\begin{array}{l}-.042 \\
(.389)\end{array}$ \\
\hline Urban population & $\begin{array}{l}113.2 * * * \\
(41.8)\end{array}$ & $\begin{array}{l}99.3^{* *} \\
(40.6)\end{array}$ & $\begin{array}{l}-151.1 * * * \\
(36.5)\end{array}$ & $\begin{array}{l}-167.7 * * * \\
(34.9)\end{array}$ & $\begin{array}{l}-.080 \\
(.058)\end{array}$ & $\begin{aligned}-.093 * \\
(.050)\end{aligned}$ & $\begin{array}{l}-6.9 \\
(7.3)\end{array}$ & $\begin{array}{l}-8.4 \\
(7.6)\end{array}$ & $\begin{array}{l}-.056 \\
(.493)\end{array}$ & $\begin{array}{l}.049 \\
(.556)\end{array}$ \\
\hline Rural population & $\begin{array}{l}168.8 * \\
(93.5)\end{array}$ & $\begin{array}{l}227.4^{* *} \\
(114.3)\end{array}$ & $\begin{array}{l}-213.4^{*} \\
(108.7)\end{array}$ & $\begin{array}{r}-127.2 \\
(99.9) \\
\end{array}$ & $\begin{array}{l}.025 \\
(.045) \\
\end{array}$ & $\begin{array}{l}-.007 \\
(.061) \\
\end{array}$ & $\begin{array}{l}.52 \\
(.44)\end{array}$ & $\begin{array}{c}.57 \\
(.43) \\
\end{array}$ & $\begin{array}{l}-.069 \\
(.050)\end{array}$ & $\begin{array}{l}-.067 \\
(.047) \\
\end{array}$ \\
\hline $\begin{array}{l}\text { Control for female } \\
\text { employment to pop. ratio }\end{array}$ & Yes & No & Yes & No & Yes & No & Yes & No & Yes & No \\
\hline $\begin{array}{l}\text { Control for female age- } \\
\text { specific death rate }\end{array}$ & No & Yes & No & Yes & No & Yes & No & Yes & No & Yes \\
\hline
\end{tabular}

All regressions include oblast and birth cohort fixed effects, and oblast-specific linear cohort trends. Each cell shows the coefficient on Sex Ratio from a separate regression. Sex ratio is the number of men from -2 to +10 years older than women of a given age range, divided by the number of women in the same age range. Regressions control for log(male pop.) and \% urban population (for 'all population' regressions). See Table 1 for sample sizes and age groups. Standard errors corrected for clustering within oblasts. *** $\mathrm{p}<$ $0.01, * * \mathrm{p}<0.05$, and $* \mathrm{p}<0.1$. 
Table 6. Summary statistics for Belarus 1999 and Ukraine 2001 Censuses, year of birth 1915-1941 (age 57-86 in 1999/2001)*

\begin{tabular}{lccll}
\hline \hline & Mean & SD & Min & Max \\
\hline \hline & & & & \\
Belarus 1999 and Ukraine 2001 combined: & & & \\
Age & 69.2 & 6.83 & 57 & 86 \\
Sex ratio & .793 & .141 & .469 & 1.13 \\
Number of children ever born & 2.02 & .271 & 1.43 & 3.52 \\
No children (=1) & .104 & .031 & .029 & .230 \\
Never married & .047 & .025 & .000 & .146 \\
Proportion urban & .529 & .239 & .088 & 1.00 \\
Number of obs. in each cell & 1304 & 936 & 30 & 5033 \\
& & & & \\
\hline \hline
\end{tabular}

*Data are collapsed by region (oblast) of residence and single year of birth. $\mathrm{N}=918$ region $\times$ birth year cells ( $N=758,558$ underlying observations). Sex ratio is the number of men from -2 to +10 years older than women of a given age in each region, divided by the number of women in the same age range (using 1959 Census data). Data are weighted by the number of observations in each cell. See Online Appendix Table 5 for descriptive statistics for Belarus and Ukraine separately. 
Table 7. Stacked regressions by single year of birth,

Belarus 1999 Census and Ukraine 2001 Census

Year of birth 1915-1941 (age 57-86 in 1999/2001)

\begin{tabular}{|c|c|c|c|}
\hline & \multicolumn{3}{|c|}{ Dependent variable: } \\
\hline & $\begin{array}{c}\text { Number of } \\
\text { children ever born } \\
\end{array}$ & No children & Never married \\
\hline & \multicolumn{3}{|c|}{ Using current region of residence to calculate sex ratio: } \\
\hline \multirow[t]{2}{*}{$\begin{array}{l}\text { Belarus and Ukraine } \\
(\mathrm{n}=918)\end{array}$} & $\begin{array}{l}.536 * * * \\
(.180)\end{array}$ & $\begin{array}{l}-.111 * * \\
(.049)\end{array}$ & $\begin{array}{l}-.120 * * \\
(.047)\end{array}$ \\
\hline & \multicolumn{3}{|c|}{ Using birthplace to calculate sex ratio: } \\
\hline $\begin{array}{l}\text { Belarus and Ukraine } \\
\qquad(\mathrm{n}=1,511)\end{array}$ & $\begin{array}{l}.724 * * * \\
(.243)\end{array}$ & $\begin{array}{l}-.214 * * * \\
(.055)\end{array}$ & $\begin{array}{l}-.161 * * \\
(.061)\end{array}$ \\
\hline Oblast and birth cohort FE & Yes & Yes & Yes \\
\hline Oblast-specific linear cohort trend & Yes & Yes & Yes \\
\hline
\end{tabular}

Each cell shows the coefficient on Sex Ratio from a separate regression. Sex ratio is the number of men from -2 to +10 years older than women of a given age in each region, divided by the number of women in the same age range (using 1959 Census data). Regressions are estimated on Census data collapsed by region (oblast) and year of birth; the underlying number of observations is $\mathrm{N}=758,558$. Regressions are weighted by the number of observations in each cell. Regressions control for $\log$ (male pop.) and \% urban population. Standard errors corrected for clustering within current region (oblast) of residence or birthplace (oblast or USSR republic). See Online Appendix Table 6 for results for Belarus and Ukraine separately. ${ }^{* *} \mathrm{p}<0.01,{ }^{* *} \mathrm{p}<0.05$, and $* \mathrm{p}<0.1$. 
For ONLINe PUblication

Online Appendix Table 1. Population and Sex Ratios by Region and Republic

\begin{tabular}{|c|c|c|c|c|c|c|}
\hline \multirow[b]{2}{*}{ Region } & \multicolumn{3}{|c|}{ Population, thous. } & \multicolumn{3}{|c|}{1959 Sex Ratio: } \\
\hline & 1939 & 1951 & Change & $25-29$ & $35-39$ & Diff. \\
\hline \multicolumn{7}{|l|}{ USSR republics: } \\
\hline RSFSR (Russia) & 108377 & 102945 & -5432 & .983 & .627 & .356 \\
\hline Ukraine & 40469 & 37223 & -3246 & .927 & .631 & .296 \\
\hline Belarus & 8912 & 7781 & -1131 & .871 & .648 & .223 \\
\hline Moldova & 2452 & 2392 & -60 & .857 & .779 & .078 \\
\hline Estonia & 1052 & 1104 & 52 & .922 & .650 & .272 \\
\hline Latvia & 1885 & 1954 & 69 & .927 & .626 & .301 \\
\hline Lithuania & 2880 & 2561 & -319 & .882 & .745 & .137 \\
\hline Armenia & 1282 & 1360 & 78 & .949 & .735 & .214 \\
\hline Azerbaijan & 3205 & 2933 & -272 & .992 & .709 & .283 \\
\hline Georgia & 3540 & 3560 & 20 & .908 & .655 & .253 \\
\hline Kazakhstan & 6082 & 6813 & 731 & 1.048 & .684 & .364 \\
\hline Kyrgyzstan & 1458 & 1764 & 306 & .951 & .690 & .261 \\
\hline Tajikistan & 1485 & 1554 & 69 & .913 & .773 & .140 \\
\hline Turkmenistan & 1252 & 1225 & 27 & .963 & .697 & .266 \\
\hline Uzbekistan & 6347 & 6434 & -87 & .930 & .697 & .233 \\
\hline \multicolumn{7}{|c|}{ RSFSR oblasts and republics: } \\
\hline Republic of Karelia & 469 & 482 & 13 & 1.009 & .579 & .430 \\
\hline Republic of Komi & 319 & 459 & 140 & 1.460 & .900 & .559 \\
\hline Arkhangelskaya oblast & 1109 & 1014 & -95 & 1.191 & .610 & .581 \\
\hline Vologodskaya oblast & 1599 & 1228 & -371 & 1.024 & .569 & .455 \\
\hline Murmanskaya oblast & 291 & 337 & 46 & 1.008 & .521 & .487 \\
\hline \multicolumn{7}{|l|}{ Northwest: } \\
\hline St. Petersburg (Leningrad) & 3385 & 2899 & -486 & .934 & .511 & .423 \\
\hline Leningradskaya oblast & 1294 & 1000 & -294 & .975 & .569 & .406 \\
\hline Novgorodskaya oblast & 1152 & 737 & -415 & .968 & .610 & .359 \\
\hline Pskovskaya oblast & 1550 & 1043 & -506 & .961 & .638 & .323 \\
\hline \multicolumn{7}{|l|}{ Central: } \\
\hline Bryanskaya oblast & 1802 & 1527 & -275 & .872 & .560 & .312 \\
\hline Vladimirskaya oblast & 1340 & 1330 & -10 & .935 & .606 & .329 \\
\hline Ivanovskaya oblast & 1388 & 1278 & -110 & .895 & .592 & .303 \\
\hline Kaluzhskaya oblast & 1178 & 891 & -287 & .954 & .596 & .359 \\
\hline Kostromskaya oblast & 1075 & 923 & -152 & 1.026 & .623 & .404 \\
\hline City of Moscow & 4542 & 5347 & 805 & .883 & .561 & .322 \\
\hline Moskovskaya oblast & 4255 & 4131 & -124 & .895 & .591 & .303 \\
\hline Orlovskaya oblast & 1286 & 926 & -360 & .983 & .638 & .344 \\
\hline Ryanzanskaya oblast & 1925 & 1437 & -488 & 1.036 & .641 & .394 \\
\hline Smolenskaya oblast & 1984 & 1220 & -764 & .991 & .598 & .393 \\
\hline Tverskaya oblast & 2489 & 1891 & -598 & .960 & .618 & .342 \\
\hline Tulskaya oblast & 1729 & 1734 & 5 & 1.000 & .651 & .348 \\
\hline Yaroslavskaya oblast & 1602 & 1364 & -238 & .971 & .600 & .371 \\
\hline
\end{tabular}


Volga-Vyatskii:

Mari-el Republic

Rep. of Mordovia

Chuvashskaya Rep.

Kirovskaya oblast

Nizhegorodskaya oblast

\section{Central Chernozem:}

Belgorodskaya oblast

Voronezhskaya oblast

Kurskaya oblast

Lipetskaya oblast

Tambovskaya oblast

Povolzhsky:

Rep. of Kalmykiya

Rep. of Tatarstan

Astrakhanskaya oblast

Volgogradskaya oblast

Penzenskaya oblast

Samarskaya oblast

Saratovskaya oblast

Ulyanovskaya oblast

\section{North Caucasus:}

Rep. of Adygeya

Rep. of Dagestan

Kabardino-Balk. Rep.

Karachaevo-Cherk. Rep.

North Ossetia

Chechnya-Ingushetia

Krasnodarskii Krai

Stavropolskii Krai

Rostovskaya oblast

\section{Urals:}

Rep. of Bashkortostan

Udmurtskaya Rep.

Kurganskaya oblast

Orenburgskaya oblast

Permskaya oblast

Sverdlovskaya oblast

Chelyabinskaya oblast

\section{West Siberia:}

Altai Republic

Altaiskii Krai

Kemerovskaya oblast

Novosibirskaya oblast

Online Appendix Table 1, continued

$\begin{array}{crrrrr}581 & 575 & -6 & .881 & .512 & .369 \\ 1185 & 983 & -202 & .898 & .559 & .339 \\ 1078 & 1026 & -52 & .846 & .509 & .337 \\ 2334 & 1916 & -418 & 1.035 & .597 & .439 \\ 3520 & 3337 & -183 & .968 & .595 & .373\end{array}$

$\begin{array}{lllrll}1440 & 1327 & -113 & .932 & .592 & .339 \\ 2709 & 2196 & -513 & .971 & .603 & .368 \\ 1773 & 1418 & -355 & .985 & .635 & .351 \\ 1353 & 1174 & -179 & .990 & .594 & .396 \\ 1878 & 1521 & -357 & 1.026 & .641 & .385\end{array}$

$\begin{array}{rrrrrr}179 & 123 & -56 & 1.149 & .679 & .470 \\ 2914 & 2686 & -228 & .927 & .589 & .338 \\ 683 & 567 & -116 & 1.010 & .661 & .349 \\ 1775 & 1444 & -331 & 1.002 & .650 & .352 \\ 1651 & 1453 & -198 & .954 & .641 & .313 \\ 1646 & 1809 & 163 & .988 & .646 & .342 \\ 2273 & 1957 & -316 & 1.014 & .657 & .357 \\ 1183 & 1108 & -75 & .956 & .643 & .313\end{array}$

\section{7}

1023

350

246

408

727

3172

1759

2893

315

1223

976

1672

2086

2610

1727

$\begin{array}{rr}\text { na } & \text { na } \\ 836 & -187 \\ 344 & -6 \\ \text { na } & \text { na } \\ 383 & -25 \\ 459 & -268 \\ 3338 & 166 \\ 1540 & -219 \\ 2756 & -137\end{array}$

$2756-137$

$2773 \quad-385$

$1181 \quad-42$

$886-90$

$1642-30$

2493

3268

2313
407

658

586

$\begin{array}{rrr}.926 & .626 & .300 \\ .901 & .659 & .242 \\ .985 & .698 & .287 \\ .974 & .723 & .251 \\ .938 & .641 & .297 \\ .929 & .683 & .256 \\ .977 & .663 & .314 \\ .969 & .656 & .313 \\ 1.032 & .659 & .373\end{array}$

$\begin{array}{rrr}.958 & .626 & .332 \\ .908 & .550 & .358 \\ .970 & .608 & .361 \\ .970 & .646 & .324 \\ 1.063 & .644 & .419 \\ 1.061 & .667 & .394 \\ .970 & .694 & .276\end{array}$

$\begin{array}{ccc}.989 & .596 & .393 \\ 1.019 & .630 & .390 \\ 1.071 & .708 & .363 \\ .983 & .635 & .348\end{array}$




\section{Online Appendix Table 1, continued}

Omskaya oblast

Tomskaya oblast

Tyumenskaya oblast

\section{East Siberia:}

Rep. of Buryatia

Tuva Republic

Rep. of Khakasiya

Krasnoyarskii Krai

Irkutskaya oblast

Chitinskaya oblast

Far East:

Sakha Republic

Primorskii Krai

Khabarovskii Krai

Amurskaya oblast

Kamchatskaya oblast

Magadanskaya oblast

Sakhalinskaya oblast

Kaliningradskaya oblast

$\begin{array}{crr}1390 & 1427 & 37 \\ 643 & 671 & 28 \\ 991 & 1000 & 9\end{array}$

$\begin{array}{lll}.999 & .642 & .357\end{array}$

$\begin{array}{lll}1.063 & .661 & .402\end{array}$

$\begin{array}{lll}.968 & .603 & .364\end{array}$

$\begin{array}{rrc}546 & 569 & 23 \\ \text { na } & 130 & \text { na } \\ 275 & \text { na } & \text { na } \\ 1960 & 2121 & 161 \\ 1303 & 1428 & 125 \\ 963 & 819 & -144\end{array}$

$\begin{array}{lll}.930 & .637 & .293\end{array}$

$.938 \quad .867 \quad .071$

$.983 \quad .677 \quad .306$

$\begin{array}{lll}1.097 \quad .746 & .352\end{array}$

$\begin{array}{lll}1.171 & .797 & .374\end{array}$

$.900 \quad .608 \quad .293$

$\begin{array}{rrcrcc}414 & 377 & -37 & 1.169 & .874 & .295 \\ 888 & 1036 & 148 & .917 & .625 & .291 \\ 657 & 791 & 134 & .946 & .683 & .262 \\ 634 & 618 & -16 & .925 & .685 & .240 \\ 109 & 122 & 13 & 1.032 & .678 & .354 \\ 173 & 166 & -7 & 1.470 & 1.091 & .379 \\ 100 & 535 & 435 & 1.112 & .743 & .369 \\ & & & & & \\ \text { na } & 455 & \text { na } & .842 & .480 & .362\end{array}$

Sources: Itogi vsesoyuznoi perepisi naseleniya RSFSR 1959 g., pp. 24-28 and Naselenie SSSR 1987, pp. 826. 


\section{Online Appendix Table 2. Means by Two-, Four-, Five-, or Ten-Year Age Group, RSFSR 1959 Census and Vital Statistics Data}

(weighted by population)

\begin{tabular}{|c|c|c|c|c|c|c|}
\hline Sex ratio, age: & $\underline{\text { All }}$ & $\underline{\text { Urban }}$ & $\underline{\text { Rural }}$ & & & \\
\hline 16-19 & 1.002 & .969 & $1 . \overline{048}$ & & & \\
\hline $18-19$ & 1.002 & .971 & 1.046 & & & \\
\hline $20-24$ & .974 & .961 & .995 & & & \\
\hline $25-29$ & .854 & .859 & .848 & & & \\
\hline $30-34$ & .738 & .755 & .716 & & & \\
\hline $35-39$ & .628 & .664 & .585 & & & \\
\hline $40-44$ & .610 & .667 & .556 & & & \\
\hline \multicolumn{4}{|c|}{ Women: } & \multicolumn{3}{|c|}{ Men: } \\
\hline Proportion married & All & Urban & Rural & All & Urban & Rural \\
\hline $16-17$ & $\overline{.024}$ & .016 & $\overline{.034}$ & $\overline{.004}$ & $\overline{.003}$ & .006 \\
\hline $16-19$ & .094 & .074 & .119 & .024 & .022 & .028 \\
\hline $18-19$ & .143 & .111 & .187 & .038 & .034 & .044 \\
\hline $20-24$ & .479 & .447 & .527 & .269 & .251 & .293 \\
\hline $25-29$ & .752 & .757 & .746 & .802 & .779 & .831 \\
\hline $30-34$ & .768 & .781 & .750 & .921 & .913 & .933 \\
\hline $35-39$ & .712 & .736 & .679 & .953 & .948 & .958 \\
\hline $40-44$ & .606 & .648 & .556 & .963 & .962 & .966 \\
\hline
\end{tabular}

Birth rate per 1,000 Archival data:

women of each age:

16-19

$18-19$

20-24

$25-29$

30-34

35-39

$40-44$ $\frac{\text { All }}{32.6} \frac{\text { Urban }}{26.2} \frac{\text { Rural }}{40.3}$

$\begin{array}{lll}50.5 & 39.4 & 65.1\end{array}$

$\begin{array}{lll}158.2 & 135.8 & 191.2\end{array}$

$\begin{array}{lll}151.7 & 125.7 & 185.5\end{array}$

$\begin{array}{lll}101.0 & 77.2 & 132.8\end{array}$

$\begin{array}{lll}55.6 & 36.8 & 81.1\end{array}$

$\begin{array}{lll}19.4 & 10.1 \quad 30.6\end{array}$
Official published data* (1959-1960):

\begin{tabular}{|c|c|c|}
\hline All & Urban & Rura \\
\hline 27.5 & 23.5 & 36.8 \\
\hline na & na & na \\
\hline 157.7 & 135.3 & 192.5 \\
\hline 154.5 & 127.8 & 189.7 \\
\hline 100.2 & 76.3 & 132.6 \\
\hline 56.5 & 37.4 & 82.4 \\
\hline 17.3 & 10.1 & 30.6 \\
\hline
\end{tabular}

Unmarried women:

$\frac{\text { All }}{8.0} \quad \frac{\text { Urban }}{5.3} \quad \frac{\text { Rural }}{11.6}$

$\begin{array}{lll}33.8 & 22.9 & 53.1\end{array}$

$\begin{array}{lll}76.4 & 56.8 & 102.2\end{array}$

$\begin{array}{lll}69.6 & 52.8 & 90.7\end{array}$

$39.5 \quad 27.5 \quad 54.2$

$\begin{array}{lll}10.3 & 6.0 & 14.9\end{array}$ 


\section{Online Appendix Table 2, continued}

Proportion of 1959 marriages with 11+ year age gap between bride and groom by age

of bride

$\begin{array}{llll}16-19 & \frac{\text { All }}{.018} & \frac{\text { Urban }}{.020} & \frac{\text { Rural }}{.016} \\ 20-24 & .005 & .005 & .004 \\ 25-29 & .012 & .012 & .012 \\ 30-34 & .050 & .049 & .051 \\ 35-39 & .129 & .132 & .126 \\ 40-44 & .172 & .168 & .177 \\ 45-49 & .168 & .153 & .187\end{array}$

Divorces per 1,000

married population:

18-19

20-24

25-29

30-39

$\frac{\text { All }}{6.7} \quad \frac{\text { Urban }}{11.7} \frac{\text { Rural }}{2.3}$

$\begin{array}{lll}13.5 & 20.4 & 5.1\end{array}$

$\begin{array}{lll}11.9 & 17.6 & 4.7\end{array}$

40-49

$\begin{array}{lll}8.3 & 11.8 & 3.5\end{array}$

$\begin{array}{lll}3.5 & 5.2 & 1.2\end{array}$

Deaths due to abortion

\begin{tabular}{clll} 
per 100 births: & $\underline{\text { All }}$ & \multicolumn{1}{l}{ Urban } & Rural \\
Age 16-19 & .065 & .070 & .062 \\
$20-24$ & .036 & .035 & .038 \\
$25-29$ & .057 & .057 & .059 \\
$30-39$ & .111 & .117 & .108 \\
$40-49$ & .208 & .260 & .184
\end{tabular}

Female employment to population ratio:

\begin{tabular}{|c|c|c|c|}
\hline Age $16-19$ & $\frac{\mathrm{All}}{.620}$ & $\frac{\text { orban }}{.537}$ & $\frac{\text { Kural }}{.725}$ \\
\hline $20-24$ & .790 & .759 & .835 \\
\hline $25-29$ & .767 & .768 & .765 \\
\hline $30-34$ & .738 & .733 & .745 \\
\hline $35-39$ & .735 & .720 & .756 \\
\hline $40-44$ & .698 & .664 & .740 \\
\hline
\end{tabular}

Female age-specific death rate

$\begin{array}{cccccc}\text { (per 1,000 pop.) } & \text { All } & & \text { Urban } & \text { Rural } & \text { Official data, all pop. (1958-59)* } \\ \text { Age } 15-19 & 1.0 & 0.8 & & 1.2 & 1.0 \\ 20-24 & 1.2 & 1.0 & 1.5 & 1.2 \\ 25-29 & 1.4 & 1.2 & 1.6 & 1.4 \\ 30-34 & 1.7 & 1.5 & 1.9 & 1.7 \\ 35-39 & 2.2 & 2.0 & 2.4 & 2.2 \\ 40-44 & 2.9 & 2.8 & 3.0 & 2.9\end{array}$

*Source: Naselenie Rossii za 100 let (1897-1997) (Population of Russia: 1897-1997), pp. 145-47, 150-51. For births, the official data are for births to mothers age $<15$ through age 19 and are therefore not comparable to the age 16-19 category for the archival data. 
Online Appendix Table 3. Additional Robustness Checks All population, unweighted OLS regressions

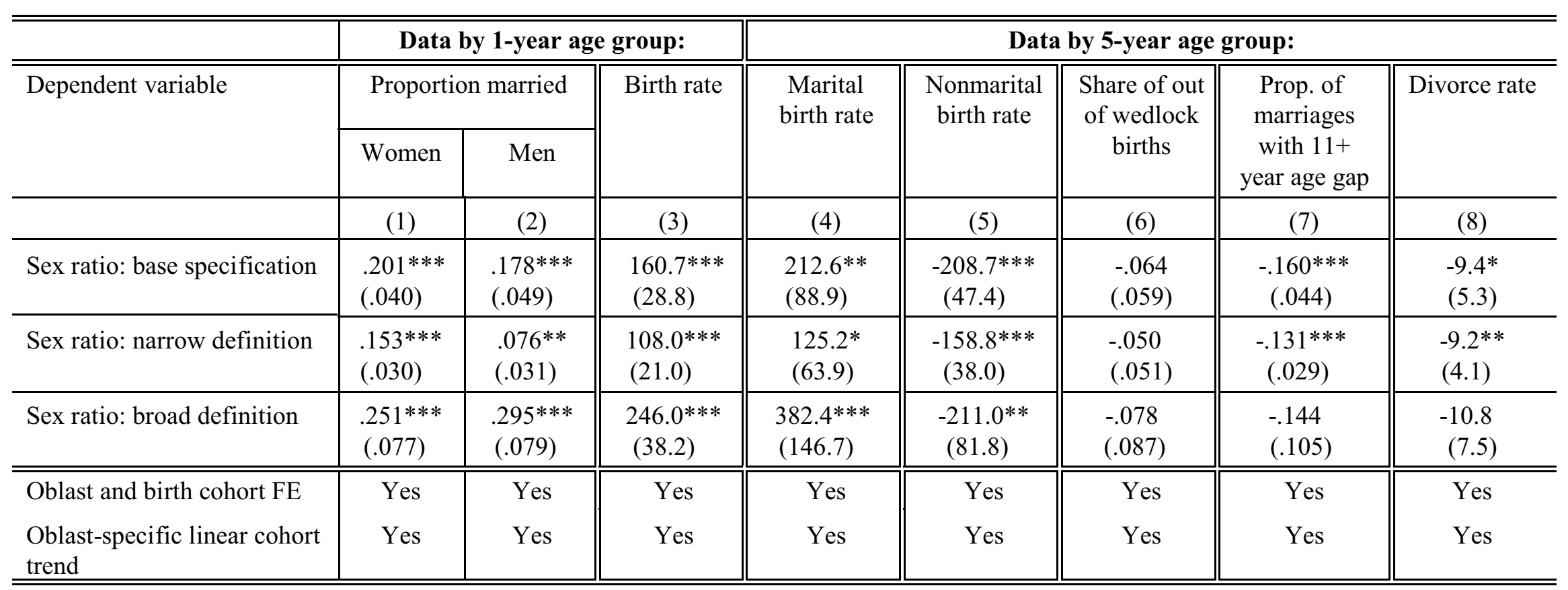

Each cell shows the coefficient on Sex Ratio from a separate regression. Sex ratio is the number of men from -2 to +10 years older than women of a given age, divided by the number of women in the same age range (base specification). The narrow definition is the number of men from -2 to +5 years older than women of a given age, divided by the number of women in the same age range, while the broad definition is men from -2 to +15 years older than women of a given age, divided by the number of women in the same age range. All regressions control for log(male pop.) (for women) or $\log ($ female pop.) (for men) and for \% urban ('all population' regressions). Standard errors corrected for clustering within oblasts. $\mathrm{N}=2025$ or $\mathrm{N}=1971$ for regressions on data by one-year age group. Marital and nonmarital birth data are for the 16-19, 20-24, 25-29, 30-34, 35-39 and 40-44 age groups ( $\mathrm{N}=437$ for all and urban regressions; $\mathrm{N}=425$ for rural regressions). 11+ year marital age gap data are for the 16-19, 20-24, $25-29,30-34,35-39,40-44$ and 45-49 age groups $(\mathrm{N}=525$ for all and urban regressions; $\mathrm{N}=511$ for rural regressions). Divorce data are for the 18$19,20-24,25-29,30-39$ and 40-49 age groups ( $\mathrm{N}=375$ for all and urban regressions; $\mathrm{N}=365$ for rural regressions). . $* * * \mathrm{p}<0.01,{ }^{*} \mathrm{p}<0.05$, and $* \mathrm{p}<0.1$. 
Online Appendix Table 4. Additional Robustness Checks

\begin{tabular}{|c|c|c|c|c|c|c|c|c|c|c|}
\hline \multirow{3}{*}{ Dependent variable } & \multicolumn{10}{|c|}{ Data by 5-year age group: } \\
\hline & \multicolumn{2}{|c|}{ Marital birth rate } & \multicolumn{2}{|c|}{ Nonmarital birth rate } & \multicolumn{2}{|c|}{$\begin{array}{c}\text { Share of out of } \\
\text { wedlock births } \\
\text { (father } \\
\text { undeclared) }\end{array}$} & \multicolumn{2}{|c|}{ Divorce rate. } & \multicolumn{2}{|c|}{$\begin{array}{c}\text { Deaths due to } \\
\text { abortion per } 100 \\
\text { births }\end{array}$} \\
\hline & OLS & WLS & OLS & WLS & OLS & WLS & OLS & WLS & OLS & WLS \\
\hline All population & $\begin{array}{l}219.3 * * \\
(93.4)\end{array}$ & $\begin{array}{c}209.8 * \\
(108.2)\end{array}$ & $\begin{array}{c}-152.8 * * * \\
(49.9)\end{array}$ & $\begin{array}{r}-120.0 \\
(74.0)\end{array}$ & $\begin{array}{l}-.090 \\
(.063)\end{array}$ & $\begin{array}{l}-.146 \\
(.096)\end{array}$ & $\begin{array}{c}-10.6 * * \\
(5.3)\end{array}$ & $\begin{array}{c}-19.6 * * * \\
(5.7)\end{array}$ & $\begin{array}{l}-.051 \\
(.371)\end{array}$ & $\begin{array}{c}.285 \\
(.384)\end{array}$ \\
\hline Urban population & $\begin{array}{c}114.9 * * * \\
(41.1)\end{array}$ & $\begin{array}{l}86.1 * * \\
(41.3)\end{array}$ & $\begin{array}{c}-149.0 * * * \\
(36.9)\end{array}$ & $\begin{array}{l}-49.4 \\
(62.8)\end{array}$ & $\begin{array}{l}-.082 \\
(.062)\end{array}$ & $\begin{array}{l}-.124 \\
(.079) \\
\end{array}$ & $\begin{array}{l}-6.3 \\
(7.5)\end{array}$ & $\begin{array}{c}-18.4 * * \\
(7.1)\end{array}$ & $\begin{array}{l}-.114 \\
(.492)\end{array}$ & $\begin{array}{c}.149 \\
(.575) \\
\end{array}$ \\
\hline Rural population & $\begin{array}{r}188.6^{*} \\
(111.4) \\
\end{array}$ & $\begin{array}{c}97.0 \\
(185.8) \\
\end{array}$ & $\begin{array}{r}-113.8 \\
(93.4) \\
\end{array}$ & $\begin{array}{l}-244.0^{*} \\
(133.9)\end{array}$ & $\begin{array}{c}.008 \\
(.061) \\
\end{array}$ & $\begin{array}{c}.054 \\
(.097) \\
\end{array}$ & $\begin{array}{l}.53 \\
(.44) \\
\end{array}$ & $\begin{array}{c}.75 \\
(.53) \\
\end{array}$ & $\begin{array}{l}-.069 \\
(.049) \\
\end{array}$ & $\begin{array}{l}-.051 \\
(.034)\end{array}$ \\
\hline Control for female emp. to pop. ratio & Yes & Yes & Yes & Yes & Yes & Yes & Yes & Yes & Yes & Yes \\
\hline Control for female age-specific death rate & Yes & Yes & Yes & Yes & Yes & Yes & Yes & Yes & Yes & Yes \\
\hline Oblast and birth cohort FE & Yes & Yes & Yes & Yes & Yes & Yes & Yes & Yes & Yes & Yes \\
\hline Oblast-specific linear cohort trend & Yes & Yes & Yes & Yes & Yes & Yes & Yes & Yes & Yes & Yes \\
\hline
\end{tabular}

Each cell shows the coefficient on Sex Ratio from a separate regression. Sex ratio is the number of men from -2 to +10 years older than women of a given age range, divided by the number of women in the same age range. WLS: regression weighted by population. All regressions control for $\log ($ male pop.) and \% urban (for 'all population' regressions). Divorce regressions also control for the male age-specific death rate. Standard errors corrected for clustering within oblasts. Marital birth data are for the 16-19, 20-24, 25-29, 30-34, 35-39 and 40-44 age groups (N=437 for all and urban regressions; $\mathrm{N}=425$ for rural regressions). Divorce data are for the 18-19, 20-24, 25-29, 30-39 and 40-49 age groups ( $\mathrm{N}=375$ for all and urban regressions; $\mathrm{N}=365$ for rural regressions). . ***p $<0.01, * * \mathrm{p}<0.05$, and $* \mathrm{p}<0.1$. 
Online Appendix Table 5: Summary statistics for Belarus 1999 and Ukraine 2001 Census data Year of birth 1915-1941 (age 57-86 in 1999/2001)*

\begin{tabular}{lllll}
\hline & Mean & SD & Min & Max \\
\hline Belarus 1999: & & & & \\
Age & 67.4 & 6.74 & 57 & 83 \\
Sex ratio & .758 & .111 & .507 & .945 \\
Number of children ever born & 2.30 & .278 & 1.65 & 3.12 \\
No children (=1) & .101 & .031 & .045 & .191 \\
Never married & .052 & .022 & .006 & .123 \\
Proportion urban & .522 & .223 & .197 & 1.0 \\
& & & & \\
Number of obs. in each cell & 810 & 228 & 124 & 1265 \\
& & & & \\
Ukraine 2001: & & & & \\
Age & 69.6 & 6.78 & 59.9 & 86 \\
Sex ratio & .801 & .145 & .469 & 1.13 \\
Number of children ever born & 1.97 & .230 & 1.43 & 3.52 \\
No children $(=1)$ & .104 & .030 & .029 & .230 \\
Never married & .046 & .025 & 0 & .146 \\
Proportion urban & .531 & .243 & .088 & 1.0 \\
& & & & \\
Number of obs. in each cell & 1407 & 993 & 30 & 5033 \\
& & & & \\
\hline
\end{tabular}

*Data are collapsed by region (oblast) of residence and single year of birth. $\mathrm{N}=189$ region $\times$ birth year cells for Belarus $(\mathrm{N}=130,881$ underlying observations $)$; $=729$ region $\times$ birth year cells for Ukraine (N=627,677 underlying observations). Sex ratio is the number of men from -2 to +10 years older than women of a given age, divided by the number of women in the same age range. Data are weighted by the number of observations in each cell. 


\section{Online Appendix Table 6. Stacked regressions by single year of birth, Belarus 1999 Census and Ukraine 2001 Census Year of birth 1915-1941 (age 57-86 in 1999/2001)}

\begin{tabular}{c|c|c|c}
\hline \hline \multirow{2}{*}{} & \multicolumn{3}{|c}{ Dependent variable: } \\
\cline { 2 - 4 } & $\begin{array}{c}\text { Number of children } \\
\text { ever born }\end{array}$ & No children & Never married \\
\hline \hline & Using current region of residence to calculate sex ratio: \\
\hline \hline $\begin{array}{c}\text { Belarus } \\
(\mathrm{n}=189)\end{array}$ & $\begin{array}{c}.774 \\
(.473)\end{array}$ & $\begin{array}{c}-.222^{* *} \\
(.074)\end{array}$ & $\begin{array}{c}-.171^{* *} \\
(.066)\end{array}$ \\
\hline $\begin{array}{c}\text { Ukraine } \\
(\mathrm{n}=729)\end{array}$ & $.458^{* *}$ & -.095 & $-.126^{* *}$ \\
$(.059)$ & $(.056)$ \\
\hline \hline & $(.189)$ & Using birthplace to calculate sex ratio: \\
\hline \hline $\begin{array}{c}\text { Belarus } \\
(\mathrm{n}=443)\end{array}$ & $1.68^{* *}$ & $-.329^{* * *}$ & $\begin{array}{c}-.250^{* *} \\
(.097)\end{array}$ \\
\hline $\begin{array}{c}\text { Ukraine } \\
(\mathrm{n}=1,068)\end{array}$ & $(.621)$ & $\begin{array}{c}-.191^{* * *} \\
(.059)\end{array}$ & $\begin{array}{c}-.157^{* *} \\
(.069)\end{array}$ \\
\hline \hline Oblast and birth cohort FE & $.479^{*}$ & Yes & Yes \\
Oblast-specific linear cohort trend & Yes & Yes & Yes \\
\hline \hline
\end{tabular}

Each cell shows the coefficient on Sex Ratio from a separate regression. Sex ratio is the number of men from -2 to +10 years older than women of a given age, divided by the number of women in the same age range. Regressions are estimated on Census data collapsed by region (oblast) and year of birth; the underlying number of observations is $\mathrm{N}=130,881$ for Belarus and $\mathrm{N}=627,677$ for Ukraine. Regressions are weighted by the number of observations in each cell. All regressions control for $\log$ (male pop.) and \% urban population. Standard errors corrected for clustering within current region (oblast) of residence or birthplace (oblast or USSR republic). . ${ }^{* * *} \mathrm{p}<0.01,{ }^{*} \mathrm{p}<0.05$, and ${ }^{*} \mathrm{p}<0.1$. 


\section{Online Appendix: Russian Longitudinal Monitoring Survey results}

Summary statistics for the RLMS variables are given in Table 7. Nearly three-quarters of women report ever having had an abortion, with three abortions on average. These figures are plausible given the high abortion rates in Russia, but the distribution of abortions is implausible with some heaping evident at 10, 15, and 20 abortions (and 37 abortions almost physically impossible). Given these problems, a 0/1 dummy variable for Ever had an abortion may produce resu9ts less subject to recall or misreporting problems.

The regressions take the same form as previous regressions, with the fertility outcome regressed on the sex ratio, log of the male population, oblast and year of birth fixed effects, and oblast-specific linear cohort trends in some regressions. The results are reported in Table 8. The relationship between total births and the sex ratio is positive, as predicted, but the coefficient is statistically insignificant in all specifications. The coefficient on number of abortions is negative, as predicted, but again the coefficients are statistically insignificant. Using a median regression to minimize the problem of outliers produces similar results, as does a Poisson regression to account for the non-negative count data (results not shown). Column (3) shows the results using Ever had an abortion has the dependent variable. The coefficient is negative and statistically significant in the first row, but becomes statistically insignificant when oblast cohort trends are included in the regression. Given the small sample size, the recall problems, and measurement error in the sex ratio it is unsurprising that these coefficients are imprecisely estimated; however the negative sign on Sex Ratio in the abortion regressions is at least suggestive that abortions increased in the low sex ratio aftermath of World War II.

Online Appendix Table 7. Descriptive statistics for RLMS data, women age 53-83 (Year of birth 1915-1941)

\begin{tabular}{lllll}
\hline \hline & Mean & SD & Min & Max \\
\hline \hline & & & & \\
Age & 64.0 & 7.2 & 53 & 83 \\
Sex ratio & .821 & .174 & .461 & 1.55 \\
Number of children ever born & 2.22 & 1.43 & 0 & 14 \\
Ever had an abortion (=1) & .741 & .438 & 0 & 1 \\
Number of abortions & 3.05 & 3.95 & 0 & 37 \\
Median number of abortions & 2 & & & \\
Share of respondents not answering & .091 & & \\
abortion questions & & & \\
Number of observations & & & & \\
& & & & \\
\end{tabular}

Sex ratio is the number of men from -2 to +10 years older than women of a given age in each region, divided by the number of women in the same age range (using 1959 Census data. based on the current region of residence). Data source: 1994-1998 rounds of the RLMS (www.cpc.unc.edu/projects/rlms-hse). 
Online Appendix Table 8. RLMS regressions, women age 53-83 (Coefficient on Sex Ratio is shown in each cell)

\begin{tabular}{l|c|c|c}
\hline \hline Dependent variable: & $\begin{array}{c}\text { Total number } \\
\text { of births } \\
(1)\end{array}$ & $\begin{array}{c}\text { Number of } \\
\text { abortions } \\
(2)\end{array}$ & $\begin{array}{c}\text { Ever had an } \\
\text { abortion? } \\
(1=\text { yes }) \\
(3)\end{array}$ \\
\hline With oblast and birth cohort fixed & 0.87 & -2.50 & $-.871^{* *}$ \\
effects & $(1.09)$ & $(3.75)$ & $(.338)$ \\
Adding oblast-specific linear cohort & 3.30 & -1.02 & -.590 \\
trend & $(2.22)$ & $(3.08)$ & $(.463)$ \\
\hline $\mathrm{N}$ & 1,959 & 1,880 & 1,883 \\
\hline
\end{tabular}

Sex ratio is the number of men from -2 to +10 years older than women of a given age in each region, divided by the number of women in the same age range (using 1959 Census data, based on the current region of residence). Regressions also include controls for rural area, $\log$ (male population), and total live births (columns 2 and 3 ). Weighted using survey weights. Standard errors clustered by region in parentheses. $* * * \mathrm{p}<0.01, * * \mathrm{p}<0.05$, and $* \mathrm{p}<0.1$. 


\section{Online Data Appendix: Archival data sources}

The archival data used in this paper were hand-collected and digitized by the author from two archives in Moscow: the GARF archive (Gosurdarstvennyi arkhiv Rossiiskoi Federatsii (State Archive of the Russian Federation)) and the RGAE archive (Rossiiskii gosudarstvennyi arkhiv ekonomiki (Russian State Archive of the Economy)). The specific location of each data series is as follows $(\mathrm{F} .=$ Fond; op. $=$ opis; $\mathrm{d} .=$ delo $)$ :

Age and sex distribution of the population by marital status, single year of age and RSFSR oblast, 1959: GARF F. 374, op. 40, d. 1, 2, 3, 4 and RGAE F. 1562, op. 336, d. 1531, 1532, 1533, 1534.

Age and sex distribution of the population by marital status, single year of age and oblast for all other USSR republics: RGAE F. 1562, op. 336, d. 1535-1548.

Total births by single year of age and RSFSR oblast, 1959: GARF F. 374, op. 31, d. 4921.

Total births by marital status and five-year age group and RSFSR oblast, 1959: GARF F. 374, op. 31, d. 4923.

Registered marriages in 1959 by age of bride and groom and RSFSR oblast: GARF F. 374, op. 31, d. 4943.

Divorces in 1959 by age and RSFSR oblast: GARF F. 374, op. 31, d. 4942.

Deaths from abortion by 2-, 5- or 10-year age group and RSFSR oblast, 1959: RGAE F. 1562, op. 27. d. $834,835,836$.

Male and female employment by 5-year age group and RSFSR oblast, 1959: RGAE F. 1562, op. 336, d. $2760,2775-2825$.

Female deaths by five-year age group and RSFSR oblast, 1959: RGAE F. 1562, op. 27, d. 826. 